\title{
Ülkemizde Nadir Küf Mantarlarına Bağlı Mikozlar: Sistematik bir Derleme
}

\author{
Mycoses due to Rare Moulds in Our Country: \\ A Systematic Review
}

\author{
Dolunay GÜLMEZ(ID) \\ Hacettepe Üniversitesi Tıp Fakültesi Tıbbi Mikrobiyoloji Anabilim Dalı, Ankara. \\ Hacettepe University Faculty of Medicine Department of Medical Microbiology, Ankara, Turkey.
}

\begin{abstract}
Makale Atıfı: Gülmez D. Ülkemizde nadir küf mantarlarına bağlı mikozlar: sistematik bir derleme. Mikrobiyol Bul 2022;56(1):143-189.
\end{abstract}

\section{ÖZ}

Dünyada ve ülkemizde mantar enfeksiyonlarının sıklı̆ı̆ı ve çeşitliliğinde artış gözlenmektedir. Nadir görülen küflere bağlı enfeksiyonlarda hasta bakım kalitesinin artırılabilmesi, erken dönemde tanı konabilmesi ve uygun tedavinin sağlanabilmesine bağlıdır. Bu enfeksiyonlara ilişkin farkındalığın sağlanabilmesi, benzer kliniğin görüldüğü olgularda tanı ve tedavi için gerekli adımların atılmasına kolaylık sağlayacaktır. Bu derlemeye dahil edilen 96 çalışmadan 165 olgunun yanı sıra, sınırlı olgu bilgisiyle nadir küf mantarı izolasyonu bildiren 28 çalışma incelenmiştir. Kriterlere uyan olgu bildiren çalışma sayısı yıllar içinde artış göstermiştir. En sık bildirilen küf Fusarium spp. $(n=74)$ olmuş, onu Scedosporium/Pseudallescheria spp. $(n=20)$ izlemiştir. Olgulardan 25 'inde dematiyöz mantar izole edilmiştir. Olgularda göz $(n=44)$, deri/ yumuşak doku $(n=35)$, dissemine $(n=34)$ periton $(n=13)$, solunum yolu $(n=13)$, sinüs $(n=12)$, merkezi sinir sistemi $(n=10)$, tırnak $(n=3)$ ve üriner sistem $(n=1)$ tutulumu saptanmıştır. Lokal başladığı halde zamanla yayılım gösteren Scedosporium apiospermum ve Fonsecaea pedrosoi'ye bağlı iki olgu bildirilmiştir. Göz tutulumlarında Fusarium spp.'nin etken olduğu iki salgın bildirimi dikkati çekmiştir. Dissemine tutulum gözlenen hastalardan sadece Exophiala dermatitidis enfeksiyonu gelişen, ikisinde bağışıklık sistemini etkileyen durum saptanmamışıtı. Periton enfeksiyonlarının hepsinde hastalarda peritoneal kateter (12 sürekli ayaktan periton diyalizi ve bir drenaj için) varlığı saptanmıștır. Merkezi sinir sistemi tutulumu olan 10 olgunun yedisinde dematiyöz mantar izole edilmiştir. Nadir küf enfeksiyonlarına bağlı olguların uygun tanı ve tedavisi, dünyada ve ülkemizde konuyla ilgili bilgi birikiminin sağlanabilmesiyle geliştirilebilecektir. Tedavi başarıının sınırlı olduğu bu enfeksiyonlarda etkenin doğru tanımlanarak erken dönemde uygun tedavinin uygulanması, klinik başarı için avantaj sağlamaktadır. Bu derleme yazıda, Sistematik Derlemeler ve Meta-Analizler için Tercih Edilen Raporlama Ögeleri [The Preferred Reporting Items for Systematic Reviews and Meta-Analyses, (PRISMA)] kuralları temel alınarak Pubmed, Scopus ve TR Dizin kayıtlarında Türkiye adresli yayınlar taranmış ve ülkemizde görülen nadir küf enfeksiyonlarının durumu tartışılmıştır.

Anahtar kelimeler: Nadir küfler; nadir küf enfeksiyonlarl; nadir mikozlar; fusarium; scedosporium.

\section{ABSTRACT}

An increase is observed in the frequency and diversity of fungal infections in the world and in our country. Improving the quality of patient care in infections due to rare moulds depends on early diagnosis and appropriate treatment. Raising awareness about these infections will facilitate taking the necessary 
steps for diagnosis and treatment in similar cases. In addition to 165 cases out of 96 studies included in this review article, 28 studies reporting rare mould isolation with limited case information were examined. The number of studies reporting cases that meet the criteria has increased over the years. The most frequently reported mould was Fusarium spp. $(n=74)$, followed by Scedosporium/Pseudallescheria spp. $(n=20)$. In 25 of the cases, dematiaceous fungi were isolated. Eye $(n=44)$, skin/soft tissue $(n=35)$, disseminated $(n=34)$ peritoneum $(n=13)$, respiratory tract $(n=13)$, sinus $(n=12)$, central nervous system $(n=10)$, nail $(n=3)$ and urinary system $(n=1)$ involvement was detected in the cases. Two cases due to Scedosporium apiospermum and Fonsecaea pedrosoi started locally but spread over time. Among eye involvements, two outbreak reports in which Fusarium spp. was the causative agent drew attention. Of the patients with disseminated involvement, only two who developed Exophiala dermatitidis infection did not have any conditions affecting the immune system. In all peritoneal infections, the patient had a peritoneal catheter (12 for continuous ambulatory peritoneal dialysis and one for drainage). In seven out of 10 cases with central nervous system involvement, dematiaceous fungi were isolated. Appropriate diagnosis and treatment of cases due to rare mould infections can be improved by providing knowledge on the subject in the world and in our country. In these infections where treatment success is limited, correct identification of the causative agent and application of appropriate treatment provides an advantage for clinical success. In this review article, publications from Turkey in Pubmed, Scopus and TR Directory records were searched based on The Preferred Reporting Items for Systematic Reviews and Meta-Analyses (PRISMA) rules and the situation of rare mould infections in our country have been discussed.

Keywords: Rare moulds; rare mould infections; rare mycoses; fusarium; scedosporium.

\section{Gíriş}

Insan enfeksiyonlarında nadir rastlanan küf mantarlarının tanısı, tanımlanması ve tedavisindeki veriler sınırıdır. Bu enfeksiyonların etkilediği hastalarda kaliteli sağlık hizmeti sağlanabilmesi için veri toplanırken, olguların nadir gözlenmesi nedeniyle gerekli veri birikiminin sağlanabilmesi için tüm dünyadan farklı amaçlarla oluşturulmuş kayıt sistemlerinden yararlanılabilmektedir ${ }^{1-3}$. Geçmişte, Avrupa Klinik Mikrobiyoloji ve Enfeksiyon Hastalıkları Derneği [European Society of Clinical Microbiology and Infectious Diseases (ESCMID)] ve Avrupa Tibbi Mikoloji Konfederasyonu [European Confederation of Medical Mycology (ECMM)] Avrupa'ya yönelik tanı/tedavi kılavuzları oluşturmuşlardır ${ }^{4,5}$. Bunlar, yerlerini tüm dünyadan uzmanların katıldığı küresel kılavuzlara bırakmaktadır. Bu amaçla ECMM, Uluslararası İnsan ve Hayvan Mikolojisi Derneği [International Society for Human and Animal Mycology (ISHAM)] ve Amerikan Mikrobiyoloji Derneği [American Society for Microbiology (ASM)] 2021'de nadir küf enfeksiyonlarının tanı ve tedavisi için bir kılavuz yayımlamışıı́ ${ }^{6}$. Ortak kılavuz, tüm dünyadan bilgi ve deneyimleri birleştirerek hasta prognozunun iyileştirilmesini hedeflemektedir.

Nadir küf mantarlarının etken olduğu enfeksiyonlar Türkiye'de de gözlenmekle birlikte, ülkemizin durumunu saptamak için kapsamlı araştırmalar henüz yeterli değildir. Richter ve Erbakan ${ }^{7}$, ülkemizde mikolojinin yeni kurulduğu bir dönemde Türkiye'deki olguları derlemişlerdir. Sık rastlanan dermatofit enfeksiyonlarının yanı sıra, sıklığın bildirilenden fazla olmasını bekledikleri madura ayağı olguları görüldüğünü ve etkenlerin araştırılması gerektiğini belirtmişlerdir. Son yıllarda, bağışıkık sistemi baskılanmış hasta sayılarındaki artışla birlikte fungal enfeksiyonların sayısı ve çeşitliliğinde artış gözlenmektedir. Bu durum, sık gözlenen Candida ve Aspergillus gibi etkenlerin oranlarında düşme ve diğer 
etkenlerin oranında artış ortaya çıkarabilmektedir ${ }^{8}$. Mantar enfeksiyonlarında, özellikle nadir görülen mantarların etken olduğu durumlarda tanının halen temel olarak konvansiyonel yöntemlere dayanması nedeniyle tanı ve etken tanımlaması zaman almaktadır ${ }^{9}$. Ülkemizde görülen fungal etkenlerin ve enfeksiyon için risk faktörlerinin araştırılması, kesin tanı öncesinde olasılıkların daha başarılı olarak ortaya konulmasına yardımcı olacaktır.

Sistematik derlemeler, belirlenen bir konuyla ilgili verilerin taranma yöntemlerinin ve elde edilen sonuçların ayrıntılı olarak belirtildiği çalışmalardır. Sistematik Derlemeler ve Meta-Analizler için Tercih Edilen Raporlama Ögeleri [The Preferred Reporting Items for Systematic Reviews and Meta-Analyses (PRISMA)] beyanında tanımlanan kurallar, bütünlük ve şeffaflık sağlayarak derlemelerin güvenilirliği ve uygulanabilirliğinin artırılması amacıyla önerilmektedir ${ }^{10}$. PRISMA kurallara öncelikle sağlık alanında müdahalenin etkilerini değerlendiren çalışmaları, tasarımlarından bağımsız olarak birlikte değerlendirebilmek amacıyla ortaya konmuş ve özellikle tanı/tedavi kılavuzlarının geliştirilmesinde kullanılmıştır. Ancak kullanılan kontrol listesinin diğer etiyoloji, yaygınlık veya prognoz incelemeleri için de uygun oldukları belirtilmiştir ${ }^{10}$. Bu çalışmada, mümkün olduğunca PRISMA önerilerine bağlı kalınarak veriler taranarak incelenmiş, yöntemler ayrıntılarıyla açıklanmıştır.

Bu sistematik derlemede, Türkiye'de rapor edilen nadir küflerin etken olduğu olguların özetlenmesi ve bu etkenler hakkında farkındalık yaratılması amaçlanmıştır.

\section{GEREÇ ve YÖNTEM}

Türkiye'den bildirilen nadir görülen küflerin etken olduğu enfeksiyonların saptanması için PubMed, Scopus ve TR Dizin veri tabanlarında PRISMA kuralları temel alınarak arama yapıldı. Aramalarda zaman kısıtlaması yapılmadı ve her dizin için zamandan bağımsız olarak tüm çalışmalar dahil edildi. Çalışmaya alınacak küf mantarları ECMM/ISHAM nadir küfler için tanı ve tedavi kılavuzuna dahil edilen etkenler göz önüne alınarak belirlendi 6 . Bu nedenle, maya mantarlarının yanı sıra Aspergillus cinsi, Mucolares takımı ve dermatofitler gibi görece daha sık rastlanan küf mantarları, dimorfik mantarlar ve Pneumocystis çalışma dışında bırakıldı.

Veri tabanlarının tarama için sunduğu özelliklerin aynı olmaması nedeniyle, tarama ve eleme süreçlerinde farklılıklar oluştu ve çok sayıda farklı arama sözcüğü kullanılması gerekti. Her veri tabanı için uygulanan süreçler aşağıda belirtildiği şekliyle açıklandı:

\section{PubMed Veri Tabanı}

"Affiliation= Turkey" ve "Species= human" filtreleri kullanılarak verilen anahtar sözcükler ile tarama yapıldı: "Hyalohyphomycosis, Phaeohyphomycosis, Chromoblastomycosis, rare Mycoses, Fusarium, Scedosporium, Lomentospora, Acremonium, Penicillium, Paecilomyces, Purpureocillium, Talaromyces, Scopulariopsis, Trichoderma, Alternaria, Exophiala, Exherohilum, Rasamsonia, Schizophyllum, Coprinopsis, Hormographiella, Cladophialophora, Fonsecaea, Philaophora, Bipolaris, Aureobasidium, Cladosporium, Curvularia, Rhinocladiella, Verticillium, Fusariosis, Scedosporiosis, Lomentosporiosis, Paecilomycosis, Penicilliosis, Talaromycosis" 
Her anahtar sözcük araması sonrasında başlık ve özet bölümleri incelenerek olgu bildirimi olmayan veya etken belirtilmeyen çalışmalar, in vitro deneysel çalışmalar ve derlemeler elenerek kalanlar seçildi. Seçilen kayıtlar "clipboard" bölümüne gönderildi ve tekrar eden kayıtlar otomatik olarak elendi.

\section{Scopus Veri Tabanı}

"Affiliation= Turkey" filtresi kullanılarak verilen anahtar sözcükler ile tarama yapıldı: "Hyalohyphomycosis, Phaeohyphomycosis, Chromoblastomycosis, rare Mycoses, Fusarium, Scedosporium, Lomentospora, Acremonium, Penicillium, Paecilomyces, Purpureocillium, Talaromyces, Scopulariopsis, Trichoderma, Alternaria, Exophiala, Exherohilum, Rasamsonia, Schizophyllum, Coprinopsis, Hormographiella, Cladophialophora, Fonsecaea, Philaophora, Bipolaris, Aureobasidium, Cladosporium, Curvularia, Rhinocladiella, Verticillium, Fusariosis, Scedosporiosis, Lomentosporiosis, Paecilomycosis, Penicilliosis, Talaromycosis"

Her anahtar sözcük araması sonrasında başlık ve özet bölümleri incelenerek olgu bildirimi olmayan veya etken belirtilmeyen çalışmalar, in vitro deneysel çalışmalar ve derlemeler elenerek kalanlar seçildi. Seçilen kayıtlar tek bir liste olarak kaydedildi ve tekrar eden kayıtlar otomatik olarak elendi.

\section{TR Dizin Veri Tabanı}

Bu dizin 1960 ve sonrasına ait yayınları içermektedir. Filtre özelliği olmadığından filtresiz olarak verilen anahtar kelimeler ile arama yapıldı: "mikoz, hiyalohifomikoz, hiyalohifomikozis, feohifomikoz, feohifomikozis, kromoblastomikoz, kromoblastomikozis, fungal enfeksiyon, fungal infeksiyon, küf enfeksiyonu, küf infeksiyonu, miçetoma, Fusarium, Scedosporium, Lomentospora, Acremonium, Penicillium, Paecilomyces, Purpureocillium, Talaromyces, Scopulariopsis, Trichoderma, Alternaria, Exophiala, Exherohilum, Rasamsonia, Schizophyllum, Coprinopsis, Hormographiella, Cladophialophora, Fonsecaea, Philaophora, Bipolaris, Aureobasidium, Cladosporium, Curvularia, Rhinocladiella, Verticillium, Fusariosis, Scedosporiosis, Lomentosporiosis, Paecilomycosis, fusaryoz"

Aramada elde edilen sonuç listesinde başlık ve özet incelenerek ön eleme yapıldı ve seçilen makale künyeleri "Excel" tablosu olarak aktarıldı.

Veri tabanlarından elde edilen tüm sonuçlar tek listede birleştirilerek tekrar eden kayıtlar elendi.Tüm veri tabanlarından elde edilen makaleler tek bir liste halinde birleştirilerek tekrar eden kayıtlar yeniden ayıklandı. Bu son listeye kaydedilen çalışmaların tam metinleri çıkarılarak değerlendirildi. Incelenen çalışmalarda kaynak gösterilen ve her üç veri tabanı taramasında da saptanamayan olgu raporları listeye eklendi. Tam metin incelemesinde Türkiye kökenli olmayan olgu bildirimleri elendi.

Mantarların taksonomisi ve isimlendirilmesinin oldukça değişken bir alan olduğu dikkate alınarak, varsa tanımlama yöntemleri belirtilerek, ilgili çalışmada verilen isimlendirme temel alındı. Tanımlama yöntemine göre bir eleme yapılmadı. Ancak kültür negatif olgular ve etkenin tanımlamasının yapılmadığı olgular dışlandı. 
Hastaya ait klinik örnekte kültürden izole edilen nadir küf üremesinin etken olarak bildirildiği çalışmalar derleme kapsamına alındı. Klinik örneklere ait kültürde üreme olmadan örneğin direkt mikroskopik incelemesi veya moleküler yöntemler ile etken tanımlaması bildiren çalışmalar dışlandı. Bu çalışmaların dışında, ayrıntılı olgu bilgisi verilmeden klinik örneklerde mantar izolasyonlarının bildirildiği sürveyans çalışmaları ve kayıtlar üzerinden olgu/etken sayısı bildirimleri yapan çalışmalar ayrı olarak listelendi.

Nadir küf mantarları için antifungal duyarlılık testleri ve değerlendirme kriterleri henüz standardize olmadığından antifungal duyarlılık ile ilgili veriler dahil edilmedi.

İstatistiksel sentez ve değerlendirme yapılmadı.

Literatür tarama ve eleme süreci Şekil 1'de PRISMA akış şemasında verilmiştir. Etken mikroorganizma ve ilgili olgu bilgisi olan 96 çalışma incelemeye dahil edilmiştir. Birden

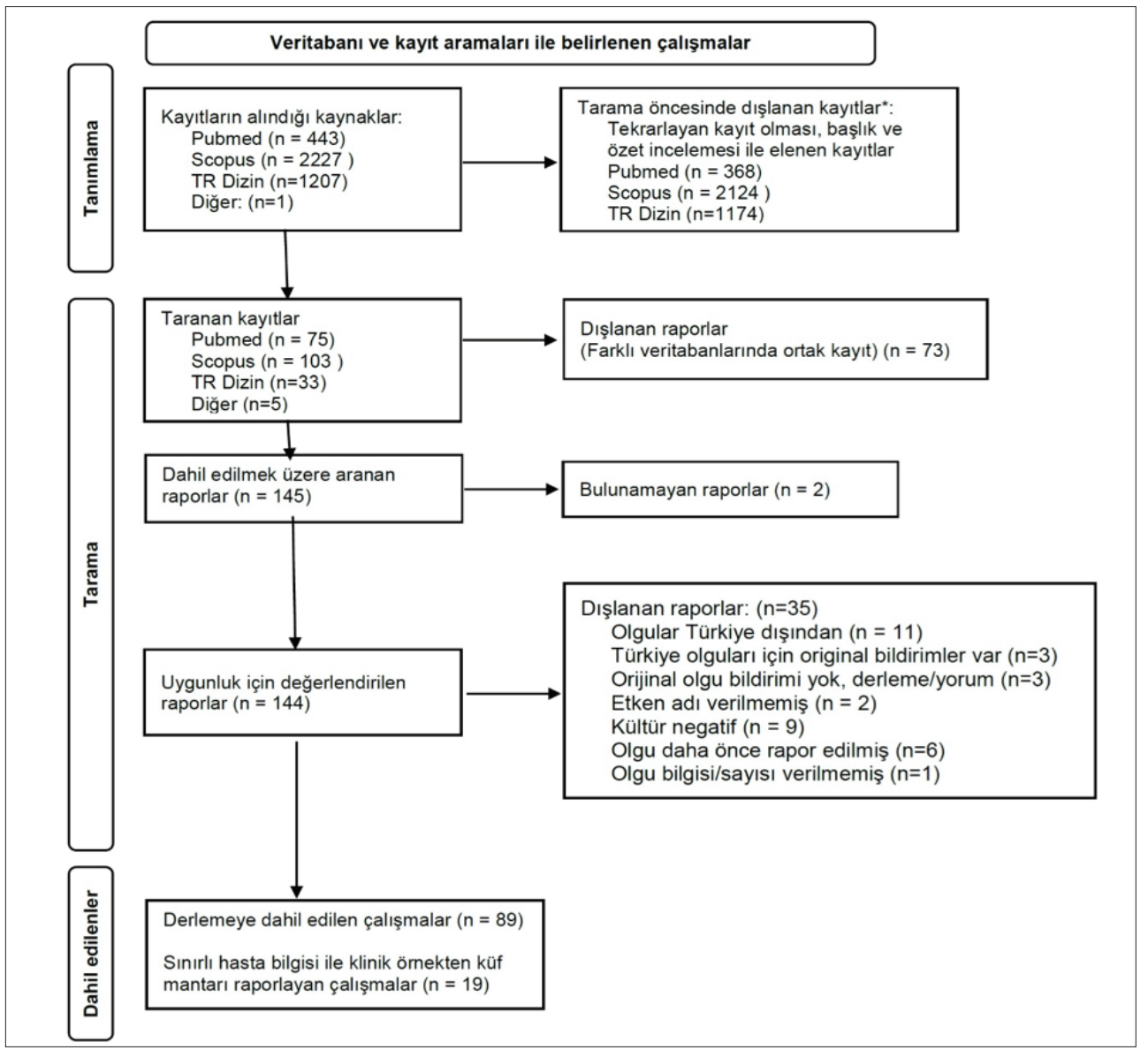

Şekil 1. PRISMA akış şeması.

*Taranan üç veritabanında filtre seçenekleri ve liste işlevi farklı olduğundan ayrıntılı açıklama gereç ve yöntemler kısmında yapılmıştır. 


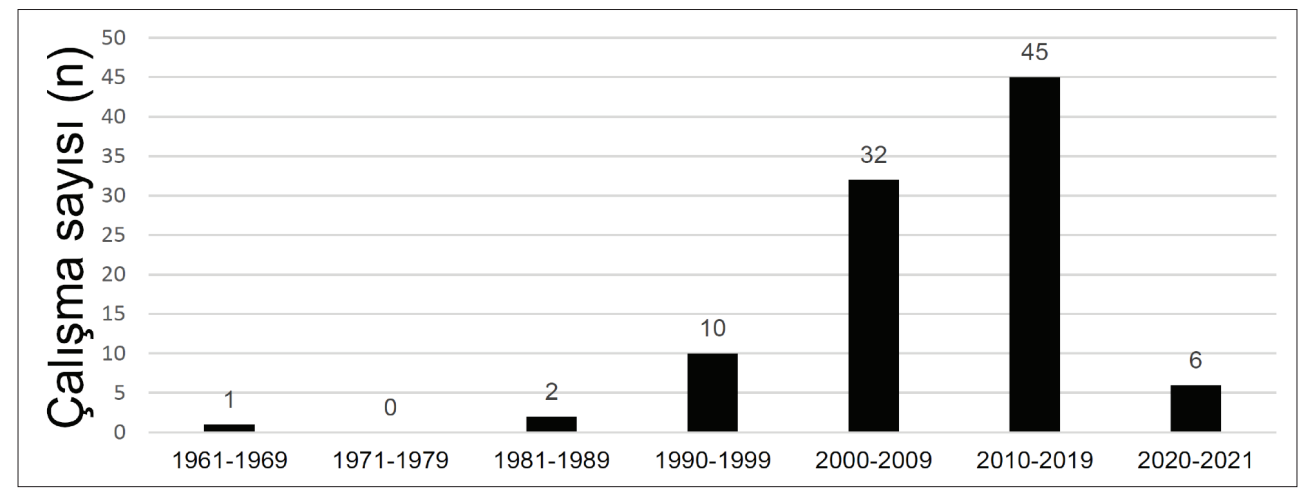

Şekil 2. Dahil edilen çalışmaların on yıllık sürelere dağılımı.

fazla rapor edilen olguların varlığında önceki çalışma alınmış, gerektiğinde daha ayrıntılı bilgi veya uzun dönem izlem için sonraki çalışmaya atıfta bulunulmuştur. Yıllar içinde olgu bildiren çalışma sayısının arttığı gözlenmiş, 10 yıllık dönemlerde klinik örneklerden nadir küf üremesi rapor eden çalışmaların sayısı Ek Şekil 1'de verilmiştir.

Bu çalışmalarda en sık bildirilen küf mantarı Fusarium türleri ( $n=74, \% 44.8)$ olmuş, bunu Scedosporium/Pseudallescheria türleri $(n=20, \% 12.1)$ izlemiştir (Tablo I). Hiyalohifomikozlara göre daha az sayıda olmakla birlikte farklı dematiyöz mantarların etken olduğu olgular ( $n=25, \% 15.2)$ da bulunmaktadır.

Derleme kapsamındaki 96 çalışmadan 15'inde direkt mikroskobik inceleme yapıldığı, 25'inde histopatolojik yöntemlerin uygulandığı belirtilmiştir (Ek Tablo I). Direkt mikroskobik incelemede potasyum hidroksit $(n=7)$, kalkoflor beyazı $(n=1)$ veya histopatolojik mantar boyalarından; periyodik asit-Schiff (PAS), $n=14$ ve/veya Gomori'nin metenamin gümüşlemesi (GMS) n= 11 kullanıldığını bildiren çalışmalar bulunmaktadır. Direkt mikroskopide Fontana-Masson gibi dematiyöz mantarları belirginleştiren boyaların kullanımına dair bilgiye rastlanmamıştır.

Rapor edilen olgularda gözlenen vücut bölgesi tutulumları Tablo II'de özetlenmiştir. En sık göz tutulumuna ( $n=44, \% 26.7)$ rastlanmıştır. Göz enfeksiyonlarına en sık Fusarium türleri (28/44, \%63.6) neden olmuştur. Deri/yumuşak doku enfeksiyonlarında ve dissemine tutulumlarda da en sık gözlenen etken Fusarium türleri olmuş (sırasıyla 14/35, \%40.0 ve 23/34, \%67.6), daha az olmakla birlikte dematiyöz mantarlara da rastlanmıştır. Merkezi sinir sistemi tutulumu bildirilen olgularda ise dematiyöz mantarların öne çıktığı (bildirilen 10 olgunun yedisi) görülmüştür.

Sistematik derleme kriterlerine uyan 96 çalışmada bildirilen etken, hasta, klinik tablo ve prognoz bilgileri Ek Tablo I'de özetlenmiştir. Bildirilen etkenin çoğunlukla sadece morfolojik olarak tanımlandığı görülmüş, bazı olgularda moleküler yöntemlerle de tanımlama yapılmıştır. Tanımlama için en sık kullanılan moleküler yöntem olan gen dizi analizi yöntemi olmuş (32 çalışma, \%33.3), bunlardan çoğunda (21/32, \%65.6) ITS geni kullanılmış- 


\begin{tabular}{|c|c|c|}
\hline \multirow[b]{2}{*}{ Rapor edilen küf mantarı } & \multicolumn{2}{|c|}{ Olgular } \\
\hline & $\mathbf{n}$ & $\%$ \\
\hline Fusarium spp. & 74 & 44.8 \\
\hline Scedosporium/Pseudallescheria spp. & 20 & 12.1 \\
\hline Acremonium spp. & 15 & 9.1 \\
\hline Penicillium spp. & 11 & 6.7 \\
\hline Paecilomyces spp. & 7 & 4.2 \\
\hline Alternaria spp. & 6 & 3.6 \\
\hline Fonsecaea spp. & 4 & 2.4 \\
\hline Aureobasidium pullulans & 3 & 1.8 \\
\hline Cladophilaphora bantiana & 3 & 1.8 \\
\hline Trichoderma spp. & 3 & 1.8 \\
\hline Bipolaris spicifera & 2 & 1.2 \\
\hline Exophiala dermatitidis & 2 & 1.2 \\
\hline Phialophora verrucosa & 2 & 1.2 \\
\hline Beauveria bassiana & 1 & 0.6 \\
\hline Chaetomium strumarium & 1 & 0.6 \\
\hline Chrysosporium spp. & 1 & 0.6 \\
\hline Cladosporium cladosporioides & 1 & 0.6 \\
\hline Curvularia lunata & 1 & 0.6 \\
\hline Cylindrocarpon lichenicola & 1 & 0.6 \\
\hline Lecythophora hofmannii & 1 & 0.6 \\
\hline Onychocola canadensis & 1 & 0.6 \\
\hline Phialemonium spp. & 1 & 0.6 \\
\hline Scopulariopsis spp. & 1 & 0.6 \\
\hline Talaromyces purpurogenus & 1 & 0.6 \\
\hline Valsa sordida (Anamorf Cyclospora) & 1 & 0.6 \\
\hline Verticillium spp. & 1 & 0.6 \\
\hline Toplam & 165 & 100.0 \\
\hline
\end{tabular}

tır. Tek başına veya ITS geni ile birlikte farklı gen dizilerini (tef1 $\alpha$, rpb2, IGS, LSU, $\beta$-tub, D1 D2 gibi) kullanan çalışmaların ( $n=11)$ yanı sıra dizilenen gen bölgesinin belirtilmediği çalışmalar $(\mathrm{n}=5)$ da bulunmaktadır (Ek Tablo I).

Sistematik derlemede incelenen 165 olguda prognozun fungal enfeksiyonun tuttuğu bölgeye ve altta yatan hastalığa göre değiştiği gözlenmiştir (Ek Tablo I). Dissemine enfeksiyon bildirilen 34 olgunun 21'inde hastanın akıbeti bildirilmiş ve bunlardan 10'unda (\%47.6) hasta kaybedilmiştir. Merkezi sinir sistemi tutulumunda da hastalarda eksitus oranı yüksektir, 10 hastadan sekizi kaybedilmiş, biri hakkında bilgi verilmemiştir. 


\begin{tabular}{|c|c|c|c|c|c|}
\hline \multirow[b]{2}{*}{ Tutulum } & \multicolumn{2}{|c|}{ Olgular } & \multirow[t]{2}{*}{ Küf mantarı } & \multicolumn{2}{|c|}{ Olgular } \\
\hline & $\mathrm{n}$ & $\%$ & & n & $\%$ \\
\hline \multirow[t]{9}{*}{ Göz } & 44 & 26.7 & Acremonium spp. & 2 & 1.2 \\
\hline & & & Alternaria spp. & 2 & 1.2 \\
\hline & & & Fonsecaea spp. & 1 & 0.6 \\
\hline & & & Fusarium spp. & $28^{*}$ & 17.0 \\
\hline & & & Paecilomyces spp. & 1 & 0.6 \\
\hline & & & Penicillium spp. & 1 & 0.6 \\
\hline & & & Scedosporium/Pseudallescheria spp. & 7 & 4.2 \\
\hline & & & Scopulariopsis spp. & 1 & 0.6 \\
\hline & & & Trichoderma spp. & 1 & 0.6 \\
\hline \multirow[t]{10}{*}{ Deri/yumuşak doku } & 35 & 21.2 & Acremonium spp. & 3 & 1.8 \\
\hline & & & Alternaria spp. & 4 & 2.4 \\
\hline & & & Aureobasidium pullulans & 1 & 0.6 \\
\hline & & & Cylindrocarpon lichenicola & 1 & 0.6 \\
\hline & & & Fonsecaea spp. & 1 & 0.6 \\
\hline & & & Fusarium spp. & 14 & 8.5 \\
\hline & & & Onychocola canadensis & 1 & 0.6 \\
\hline & & & Paecilomyces spp. & 1 & 0.6 \\
\hline & & & Phialophora verrucosa & 1 & 0.6 \\
\hline & & & Scedosporium/Pseudallescheria spp. & 8 & 4.8 \\
\hline \multirow[t]{7}{*}{ Dissemine } & 34 & 20.6 & Acremonium spp. & 4 & 2.4 \\
\hline & & & Aureobasidium pullulans & 1 & 0.6 \\
\hline & & & Exophiala dermatitidis & 2 & 1.2 \\
\hline & & & Fusarium spp. & 23 & 13.9 \\
\hline & & & Scedosporium/Pseudallescheria spp. & $2^{* *}$ & 1.2 \\
\hline & & & Trichoderma spp. & 1 & 0.6 \\
\hline & & & Verticillium spp. & 1 & 0.6 \\
\hline \multirow[t]{8}{*}{ Periton } & 13 & 7.9 & Acremonium spp. & 4 & 2.4 \\
\hline & & & Bipolaris spicifera & 1 & 0.6 \\
\hline & & & Curvularia lunata & 1 & 0.6 \\
\hline & & & Fusarium spp. & 1 & 0.6 \\
\hline & & & Lecythophora hofmannii & 1 & 0.6 \\
\hline & & & Paecilomyces spp. & 3 & 1.8 \\
\hline & & & Penicillium spp. & 1 & 0.6 \\
\hline & & & Trichoderma spp. & 1 & 0.6 \\
\hline
\end{tabular}




\begin{tabular}{|c|c|c|c|c|c|}
\hline \multirow[b]{2}{*}{ Tutulum } & \multicolumn{2}{|c|}{ Olgular } & \multirow[t]{2}{*}{ Küf mantarı } & \multicolumn{2}{|c|}{ Olgular } \\
\hline & $\mathbf{n}$ & $\%$ & & $\mathbf{n}$ & $\%$ \\
\hline \multirow[t]{6}{*}{ Solunum yolu } & 13 & 7.9 & Acremonium spp. & 2 & 1.2 \\
\hline & & & Beauveria bassiana & 1 & 0.6 \\
\hline & & & Bipolaris spicifera & 1 & 0.6 \\
\hline & & & Fusarium spp. & 5 & 3.0 \\
\hline & & & Scedosporium/Pseudallescheria spp. & 3 & 1.8 \\
\hline & & & Talaromyces purpurogenus & 1 & 0.6 \\
\hline \multirow[t]{6}{*}{ Sinüs } & 12 & 7.3 & Aureobasidium pullulans & 1 & 0.6 \\
\hline & & & Chaetomium strumarium & 1 & 0.6 \\
\hline & & & Chrysosporium spp. & 1 & 0.6 \\
\hline & & & Penicillium spp. & 7 & 4.2 \\
\hline & & & Phialophora verrucosa & 1 & 0.6 \\
\hline & & & Valsa sordida (Anamorf Cyclospora) & 1 & 0.6 \\
\hline \multirow[t]{6}{*}{ Merkezi sinir sistemi } & 10 & 6.1 & Cladophialophora bantiana & 3 & 1.8 \\
\hline & & & Cladosporium cladosporioides & 1 & 0.6 \\
\hline & & & Fonsecaea spp. & 2 & 1.2 \\
\hline & & & Paecilomyces spp. & 1 & 0.6 \\
\hline & & & Penicillium spp. & 2 & 1.2 \\
\hline & & & Phialemonium spp. & 1 & 0.6 \\
\hline Tirnak & 3 & 1.8 & Fusarium spp. & 3 & 1.8 \\
\hline Üriner sistem & 1 & 0.6 & Paecilomyces spp. & 1 & 0.6 \\
\hline Toplam & 165 & 100.0 & & 165 & 100.0 \\
\hline
\end{tabular}

Ayrıntılı olgu bilgisi verilmeden klinik örneklerde mantar izolasyonlarının bildirildiği 28 çalışma Ek Tablo II'de gösterilmiştir. Bunlar arasında, uluslararası veri tabanlarına yapılan kayıtlar, farklı enfeksiyonlarda etken mikroorganizma tarayan çalışmalar ve mikoloji laboratuvarında izole edilen etkenleri bildiren raporlar bulunmaktadır.

\section{TARTIŞMA}

Sağlık sisteminde yoğun bakımlarda yatan ve/veya bağışıklık sistemi baskılanmış hasta sayılarının artması, yatış sürelerinin uzaması, tekrarlayan invaziv girişimler ve travma gibi durumlar nedeniyle farklı klinik tablolarla ortaya çıkan mantar enfeksiyonları daha sık gözlenmektedir ${ }^{4,6,11}$. Mantar enfeksiyonlarındaki artış, kliniklerde ve mikrobiyoloji laboratuvarlarında fungal etkenlere karşı bir farkındalık gelişmesine olanak sağlamıştır. Bu durum, daha önce ihmal edilen bazı hastalıkların tanı almasına ve nadir görülen fungal 
etkenlerin ülkemizde de tanımlanmasına zemin hazırlamaktadır. Bu sayede, ülkemizde fungal enfeksiyonların tanı ve tedavisinde kalitenin artması mümkün olacaktır. Enfeksiyon etkeninin mantar olduğunun saptanması ve mantarın tanımlanabilmesi, hastanın prognozunda önemli rol oynamaktadır.

Nadir görülen fungal etkenlere bağlı enfeksiyonlarda tanı direkt mikroskopi ve kültüre dayanmaktadır. Erken tanıda direkt mikroskopi, özellikle mantara özgü boyalar olan kalkoflor beyazı, GMS ve PAS boyaları kullanıldığında yararlı olabilmektedir. Ancak, negatif sonuçlar tanıyı ekarte etmemektedir. Ayrıca, deneyimin sınırlı olduğu durumlarda fungal yapıların değerlendirilmesinde hatalar yapılabilmektedir ${ }^{9}$. Yücel, S.apiospermum'un etken olduğu bir panoftalmide, enükleasyon materyalinin HE ve PAS ile histopatolojik incelemesinin negatif olarak bildirildiğini ancak mikoloji laboratuvarında hiflerin tespit edildiğini bildirmiştir ${ }^{12}$.

Etkenin kültürde üretilmesi, nadir küf mantarlarının kesin olarak tanımlanabilmesi için ilk basamaktır. Kültürde üretilen küflerin makroskopik ve mikroskopik morfolojilerinin incelemesi, çalışmaların çoğunda kullanılan tanımlama yöntemi olmuştur. Kültürde üretilen küf mantarında, çeşitli besiyerlerinde farklı koşullarda gelişen morfoloji incelenebilmektedir. Ancak, histopatolojik incelemede gözlenen morfoloji belirli koşullarla sınırlı kalmakta ve bazı durumlarda yanıltıcı olabilmektedir. Örneğin Sili ve arkadaşları ${ }^{13}$, pulmoner nodülün histopatolojik incelemesinde gözlenen fungal elemanların Candida ön tanısı ile rapor edildiğini, parafin bloktan elde edilen DNA ITS genine özgü primerlerle çoğaltılıp dizilendiğinde ise Talaromyces spp. olarak tanımlandığını bildirmişlerdir. Bu nedenle, sadece histopatolojik incelemeyle tanımlama yapılan kültür negatif olgular, çalışmaya dahil edilmemiştir.

Özellikle daha yakın zamanlı çalışmalarda, başta ITS olmak üzere farklı genlerin dizi analizi ile cins ve tür düzeyinde tanımlama doğrulanmıştır. Mantar enfeksiyonu tanısında hasta örneklerinden doğrudan yapılan moleküler testlerin kullanımına ilişkin öneriler henüz Aspergillus gibi daha sık görülen patojenler ile sınırlıdır ${ }^{8}$. Bu nedenle, kültürde üreme olmadan hasta örneğinden doğrudan moleküler yöntem kullanarak bildirim yapan çalışmalar da derlemeye alınmamıştır.

Kültürde üreyen küf mantarlarının tanımlanmasında morfoloji önemlidir. Ancak, in vitro üremelerde farklı veya dejenere morfolojiler de gözlenebildiği akılda tutulmalıdır. Ersal ve arkadaşları ${ }^{14}$, fatal dissemine enfeksiyona yol açan bir Fusarium petroliphilum suşunun tipik morfolojisinin ancak birkaç hafta sonra pasajlanan kültürlerde gözlenebildiğini belirtmişlerdir. Kantarcıoğlu ve arkadaşları ${ }^{15}$ farklı besiyerlerinde koyu ve açık renkli koloniler oluşturan bir Fusarium v izolatı bildirmişlerdir. Tipik morfolojinin gözlendiği durumlarda bile, deneyimi sınırlı laboratuvarlarda tanımlamada sorun yaşanabilmektedir. Ayrıca, nadir küf mantarlarında antifungal duyarlılık durumunun ve dolayısıyla uygun antifungal tedavi seçeneklerinin cins ve tür düzeyinde farklılık gösterdiği bilinmektedir ${ }^{1,4-6}$. Etken mantar ve etkili tedavi seçenekleri hakkında toplanan verinin güvenilir olması amacıyla, 
morfolojik tanının yanı sıra dizileme çalışmalarıyla tür düzeyinde tanımlama yapılması önerilmektedir. Uygun ve yeterli veri tabanı olması durumunda MALDITOF-MS yöntemiyle de tür düzeyinde tanımlama başarılı olabilmektedir ${ }^{6}$. Ülkemizdeki çalışmalarda da moleküler düzeyde tanımlaması doğrulanan etkenler bulunmaktadır (Ek Tablo I). Tür düzeyinde doğru tanımlama yapılabilmesi için eldeki dizinin ayrıntılı değerlendirilmesi veya birden fazla gen dizisinin incelenmesi gerekebilmektedir. Doymaz ve arkadaşları ${ }^{16}$, etkenin ITS1 ve ITS2 gen dizilerini standart suş ile karşılaştırarak Fonsecaea pedrosoi ile Fonsecaea monophora ayrımını yapabilmişlerdir. Dalyan Cilo ve arkadaşları ${ }^{17}$ Fusarium suşlarını önce tür kompleksi, sonra tür düzeyinde tanımlayabilmek için ITS ve TEF-1 $\alpha$ genlerinin yanı sıra rpb2, IGS, LSU ve $\beta$-tübülin gen dizilerini kullanmışlardır. Bir çalışmada Fusarium sporotrichoides tanımlaması için özgül polimeraz zincir reaksiyonu kullanılmıştır ${ }^{18}$. MALDITOF-MS yöntemini kullanan iki çalışmada F.solani ve Scedosporium boydii tanımlanmış, S.boydii tanımlaması ITS dizileme ile de doğrulanmıştır ${ }^{19,20}$. Morfolojik tanıya ek olarak moleküler doğrulama yapılması kesin tür tanımlaması için yararlı olsa da özellikle eski tarihli çalışmalarda yapılamamıştır. Bu nedenle, tanımlama yöntemine göre bir eleme yapılmamış, bildirilen cins ve tür belirtilmiştir.

Mantar enfeksiyonu şüphesi olan bir hastada, tanıda kültür duyarlılığını istenen düzeyde olmadığı bilinmektedir ${ }^{8}$. Buna ek olarak, eş zamanlı bakteriyel enfeksiyon varlığı durumunda, daha yavaş üreyen fungal patojenlerin tespit edilmesi sorun olabilmektedir. Akova Budak ve arkadaşları ${ }^{21}$, keratit tanısıyla alınan ilk kornea kazıntısında Staphylococcus warneri üreyen; ancak, antibiyotik tedavisine yanıt alınamayan bir hastanın ikinci örneğinde Fusarium spp. ürediğini bildirmişlerdir. Uludokumacı ve arkadaşları ${ }^{22}$ ise, ektima gangrenosum gelişen nötropenik bir hastada çoklu kan ve deri biyopsi örneklerinde Pseudomonas aeruginosa üremesi yanı sıra benzer bir lezyondan Fusarium ürediğini bildirmiştir. Bu hastada ek olarak fungal endoftalmit gelişmiştir.

Etkenin erken dönemde doğru tanımlanması, uygun tedavinin seçimini ve hastanın prognozunu etkilemektedir. Hayatı tehdit eden invaziv fungal enfeksiyonlarda uygun tedavinin önemi daha fazla öne çıkmaktadır. Etkene ait doğal direnç, in vitro duyarlılık ve tedavi başarısı verileri elde edildikçe tedavi önerileri netleşmektedir. Etkenlerin antifungal duyarlıık durumunun bilinmediği ve tedavi seçeneklerinin sınırlı olduğu dönemlerde ve sonraki dönemlerde tedavi önerilerinden çıkarılan antifungal ajanların kullanıldığı olgular bulunmaktadır ${ }^{4}$. Bu durumlarda hastanın prognozu, bağışıklık sisteminin durumundan oldukça etkilenmektedir. Yıldıran ve arkadaşları ${ }^{23}$ iki nötropenik hastada flukonazol ile tedavi edilmeye çalışılan Fusarium fungemisi bildirmiş, hematolojik remisyon sağlanabilen bir hastanın iyileştiğini belirtmişlerdir. Kiraz ve arkadaşları ${ }^{24}$; daha önce invaziv pulmoner aspergilloz nedeniyle antifungal tedavi almış nötropenik bir hastada ateş varlığında alınan beş kan kültürünün ikisinde Acremonium spp. izole etmiş, G-CSF tedavisi ile nötropenisi düzelen hastada tedavi verilmediği halde sonraki kültürlerde üreme olmamıştır. Bu derlemeye dahil edilen 33 dissemine fungal enfeksiyon olgusundan sadece üçünde bağışıklık sistemini etkileyen bir durum rapor edilmemiştir. Bunlardan ikisinde etken olan Exophiala 
dermatitidis'in immün kompetan kişilerde de yaygın enfeksiyon yapabildiği bilinmekte$\operatorname{dir}^{25,26}$. Üçüncü hastada ise lezyonlar kortikosteroid enjeksiyonu sonrasında gelişmiştir ${ }^{27}$.

Araştıılan olgularda en sık göz tutulumu (\%26.7) bildirilmiştir. Dünyada fungal keratitlerin çoğu uygun tıbbi tedaviye ulaşmakta güçlük çeken kırsal bölgelerde geliştiğinden, bildirilen tedavi başarıları düşüktür. Kornea perforasyonu ve/veya enükleasyon oranları \%10-25 arasında değişmektedir. Korunabilen gözlerde de korneada gelişen opasiteler nedeniyle görme kayıpları \%60'lara ulaşabilmektedir ${ }^{11}$. Bu çalışmada Ek Tablo I'de verilen 44 olgunun 37'sinde görme ile ilgili bilgi bulunmaktadır. Bu olguların dördünde göz kaybedilmiştir. Gözün kaybedildiği olguların ikisinde etken F.solani, birinde S.apiospermum'ken; bir olguda Acremonium spp. ve Pseudomonas mesophilica ile karışık enfeksiyon bildirilmiştir ${ }^{12,28-30}$. Göz kaybı yaşanan ve F.solani'nin etken olduğu iki olgunun iyatrojenik salgınlar sonucunda gerçekleşmiş olması üzücüdür ${ }^{29,30}$. Olgulardan 25 'inde görmede kayıp olduğu bildirilmiş, beş hastada keratoplasti yapılmış veya önerilmiş, bir hastada görme kaybı normal sınırlar içinde (0.8) kalmışır. Diğer iki olguda ise korneada etkilenen kısmın görme hattının dışında kalması, sonucu olumlu etkilemiştir.

Fungal keratitlerde oküler travma ile organik materyal (toprak, bitki atıkları vb.) bulaşı ve kontakt lens kullanımı risk faktörleri olarak öne çıkmaktadır ${ }^{11}$. Derlemeye alınan olguların 12'sinde oküler travma, 22'sinde ise göz ameliyatı sonrasında enfeksiyon gelişmiş, iki hastada kontakt lens kullanımı bildirilmiştir. Ameliyat sonrasında gözlenen olgu sayısı dikkat çekicidir. Bunun nedeni aynı merkezden bildirilen, katarakt operasyonu sonrasında gelişmiş Fusarium spp.'ye bağlı iki farklı iyatrojenik salgındır29,30. Salgınlardan, kültürle kanıtlanamamakla birlikte, ameliyat sırasında ortak olarak kullanılmış olan antibiyotik solüsyonunun kontamine olmasının sorumlu olduğu gösterilmiştir.

Küf mantarları ve özellikle Fusarium türleri, önemli fungal keratit etkenleridir ${ }^{11}$. íki nozokomiyal salgından bildirilen olgular çıkarıldığında bile, göz tutulumuna en sık neden olan küf mantarının Fusarium spp. olduğu görülmüştür $(n=11)$. Dematiyöz mantarlar da göz tutulumuna neden olabilmektedir. Dünyadan bildirilen olgularda en sık Curvularia türlerinin etken olduğu belirtilmiştir ${ }^{11}$. Bu derlemeye dahil edilen çalışmalarda ise Alternaria spp. ve Fonsecaea spp. izole edilen olgular görülmüştür ${ }^{31-33}$.

Göz enfeksiyonlarında da geçmiş raporlar tedavi seçeneklerindeki sınırlı durumu yansıtmaktadır. Coşkun ve arkadaşlar ${ }^{28}$ oküler travma sonrasında Acremonium spp. ve Pseudomonas mesophilica ile gelişen bir keratit olgusunda tedavi amacıyla flukonazol kullanıldığını ve enfekte gözün kaybedildiğini bildirmişlerdir. Ancak, bu olgunun prognozunu etkileyen durumlar arasında eş zamanlı bakteriyel enfeksiyonun da göz önünde tutulması uygun olacaktır.

Hayatı tehdit etmeyen mikozlarda da mikolojik tanının doğru konabilmesi hastanın hayat kalitesini oldukça etkileyebilmektedir. Örneğin, bu derlemeye dahil edilen çalışmalar içinde en eski miçetoma olgusu 1967'de bildirilmiş; 29 yaşındaki kadın hastanın 10 yıldır ayağındaki lezyon ile yaşadığı, etkenin Allescheria boydii (S.apiospermum) olduğu ve 
dönemin koşullarında tedavi edilemediği bildirilmiştir ${ }^{34}$. Barış ve arkadaşları ${ }^{20}$ da $2021^{\prime}$ de yaklaşık 20 yıl sonra tanı konan S.apiospermum'un etken olduğu bir miçetoma olgusu bildirmiştir. Ancak, bu hasta geç tanı almış olsa da başarıyla tedavi edilebilmiştir. Erbağcı ve arkadaşları $^{35}$ ise yüzünde 20 yıldır eritematöz lezyonları ve altı yıldır nodülleri bulunan bir hastada Acremonium strictum'a bağlı kutanöz enfeksiyon tanımlamış ve hastayı tedavi etmişlerdir. İstanbul'dan bildirilen hayatı tehdit etmeyen üç Scedosporium enfeksiyonunda, tedavi almayan iki olgudan birinde ekstremite ampütasyonu ${ }^{36}$, ikincisinde ise göz enükleasyonu ${ }^{12,36}$ gerekmiştir. Itrakonazol tedavisi alan ve cerrahi debridman yapılan üçüncü hastada ise ateşli silah yaralanmasından sonra gelişen ve üç yıldır devam eden osteomiyelit başarıyla tedavi edilmiştir ${ }^{36,37}$. Erbağcı ve arkadaşları ${ }^{38}$ altı ay öncesinde deri lezyonları gelişen bir hastada 10 yıldır tedavi edilemeyen onikomikoz sonrası klinik örnekte Onychocola canadensis izole edilmiş ve hastada itrakonazol ile kısmi şifa sağlanmıştır.

Nadir küf mantarlarıyla gelişen yüzeysel lezyonlarda bile tedavi sorunları yaşanabildiği akılda tutulmalıdır. Hilmioğlu ve arkadaşları ${ }^{39}$, Acremonium spp.'nin etken olduğu kutanöz enfeksiyonun tedavisinde flukonazol ve itrakonazolün yetersiz kaldığı bir hastada L-amfoterisin B ile böbrek yetmezliği geliştiğini bildirmiştir. Hasta hemodiyalize girmek zorunda kalmış, L-amfoterisin B tedavisi kesilmiş, ancak yeniden başlanan itrakonazol tedavisi ile iyileşme sağlanabilmiştir.

Küf mantarlarının neden olduğu deri/yumuşak doku enfeksiyonları sıklıkla travma sonrasında etkenin deri altına yerleşmesi sonrasında gelişmektedir. Bildirilen olgularda lezyonlar travmaya açık bölgeler olan ayak, el ve ekstremitelerde yoğunlaşmıştır. Olguların üçünde travma öyküsü ${ }^{15,37,40}$, üçünde de çıplak ayakla yürüme alışkanlığı ${ }^{18,38,41}$ bildirilmiştir. Fonsecaea pedrosoi'nin izole edildiği akut lenfoblastik lösemi hastası bir çocukta da dental enfeksiyon gözlenmiştir ${ }^{42}$.

Öte yandan, lokal başlayan fungal enfeksiyonların erken tanı ve tedavisi de yayıIımın önlenmesi için önem taşımaktadır ${ }^{4}$. Yüze yapılan steroid enjeksiyonu sonrasında servikal lenfadenopati gelişen bir hasta hatalı tüberküloz lenfadeniti tanısı ile izlenmiştir. Lezyonların yayılması ve göz tutulumunun başlaması ile yapılan ek tetkikler, etkenin S.apiospermum olduğunu ortaya çıkarmıştır ${ }^{27}$. Hasta, itrakonazol ile tedavi edilebilmiştir. Fungal yayılım hastanın hayatını tehdit edebilmektedir. Artüz ve arkadaşları ${ }^{43}$, gebelik sırasında yedi yıldır kutanöz lezyonları olan immün kompetan bir hastadan Fonsecaea pedrosoi izole etmiş, ancak doğum sonrası tedavi için doktora başvurmayan hastanın bir yıl sonra beyin tutulumu ile kaybedildiği ve beyin biyopsisinde aynı mikroorganizmanın izole edildiği bildirilmiştir.

Periton diyaliz sıvısından izole edilen küf mantarlarında çeşitlilik öne çıkmaktadır. Hastaların tamamında peritoneal kateter bulunması [sürekli ayaktan periton diyalizi $(n=12)$, karaciğer nakli sonrası safra sızıntısı $(n=1)$ nedeniyle] mikroorganizma kolonizasyonunu ve sonrasında enfeksiyon gelişimini kolaylaştırmıştır. Hastalardan birinde kültürde izole edilen Curvularia spp.'nin sadece kateter obstrüksiyonuna neden olduğu bildirilmiştir ${ }^{44}$. Bir hastada da izole edilen Paecilomyces crustaceus'un kateteri kolonize ettiği ama peri- 
tonit gelişmediği, antifungal verilmeden kateter çekilerek hastanın tedavi edildiği bildirilmiştir ${ }^{45}$. Peritonit gelişen olgularda da, antifungal tedavinin yanı sıra kateterin çekilmesine öncelik verilmiştir ${ }^{46-52}$. Kateterin hemen çekilemediği durumlarda, rekürrensin önlenebilmesi için antifungal tedaviye devam edilmesi gerekmiştir ${ }^{47}$. Peritonitlerde bağırsak mikrobiyotasında bulunan bakterilerin ve Candida türlerinin öncelikle akla gelmesi, küf mantarlarının etken olduğu olgularda tedavinin gecikmesine neden olabilmektedir. Ay Altıntop ve arkadaşları ${ }^{53}$ fungal peritonit şüphesi ile flukonazol başlanan bir hastanın tedavisinin kültürde Acremonium spp. üremesini takiben tedavinin amfoterisin B'ye değiştirildiğini ancak hastanın ilk dozdan sonra kaybedildiğini bildirmiştir. Fungal peritonit olgularında da, tedavi seçeneklerinin sınırlı olduğu dönemlerde, küf etkinliği sınırlı bir antifungal ajan olan flukonazolün kullanıldığı ve kateterin çekilebildiği durumlarda başarı sağlanabilen olgular bulunduğu bildirilmiştir ${ }^{49}$.

Nadir görülen küf mantarları solunum yolundan da izole edilmiştir. Bu derlemeye alınan olguların tamamında bağışıklık sistemini ve/veya akciğerleri etkileyebilecek, altta yatan bir hastalık bulunmaktadır (Ek Tablo I). Prognoz hakkında bilgi bulunan yedi hastanın dördü kaybedilmiştir. Bu hastalardan ikisinde etken Acremonium spp. iken, bir hastada S.apiospermum, bir hastada da Talaromyces purpurogenus bildirilmiştii ${ }^{54-57}$. S.apiospermum enfeksiyonu olan bir hasta antifungal (vorikonazol) tedavisi altında taburcu edilmiştir ${ }^{58}$. Bronşektazi kolonizasyonu olarak tanı alan ve beş yıldır öksürük, balgam, hemoptizi şikaketleriyle takip edilen bir hastada durum lobektomi ile kontrol altına alınmıştır ${ }^{59}$.

Merkezi sinir sistemi tutulan 10 olgudan altısının immün kompetan oldukları görülmüştür. Bu olgulardan yedisinde etkenin dematiyöz bir mantar olduğu bildirilmiştir. Nörotropik özelliği ile bilinen Cladophialophora bantiana tespit edilen üç immün kompetan olgu bulunmaktadır. Bu olgulardan biri kaybedilmiş ${ }^{60}$, ikisi oral vorikonazol tedavisi ile taburcu edilmiştir ${ }^{61,62}$. Merkezi sinir sisteme ait tutulum bulguları, özellikle bağışıklık sistemi baskılanmış bireylerde dissemine enfeksiyonun ilk belirtisi olarak da karşımıza çıkabilmektedir. Alpaydın ve arkadaşları ${ }^{63}$ iki ay önce böbrek nakli geçiren 39 yaşındaki kadın hastada bilinç değişikliği ve hemiparezi ile tanı konan bir P.boydii enfeksiyonu bildirmişlerdir. Bu hastanın ileri tetkikleri, akciğer ve pankreasta da tutulum olduğunu göstermiş, hasta kaybedilmiştir.

Kriterlere uyan çalışmalarda onikomikoz olgularının sayısının düşük olduğu görülmektedir (Tablo II) ${ }^{17}$. Bir olguda da deri lezyonlarının yanı sıra, tedaviyle düzelme sağlanamayan tırnak tutulumu bildirilmiştir ${ }^{35}$. Ancak fungal deri/tırnak enfeksiyonu şüphesinde öncelikle direkt mikroskopi ile tanı konmakta; tedaviye yanıt vermeyen olgularda kültür istenmektedir. Antifungal maruziyeti sonrası alınan örneklerde etkenin üremesi ve üreyen mikroorganizmada tipik morfolojinin gözlenmesi güçleşmektedir ${ }^{9}$. Epidemiyolojik çalışmalarda dermatofit ve Aspergillus spp. dışı onikomikoz olgularının bildirilmiş olması, tedaviye dirençli olgularda nadir küflerin etken olarak akla gelmeleri gerektiğini hatırlatmaktadır (Ek Tablo II). 


\section{SONUÇ}

Mantar enfeksiyonlarının sıklık ve çeşitliliğindeki artış tüm dünyadan ve ülkemizden bildirilmektedir. Bu sistematik derleme, ülkemizde yıllar içinde nadir küf mantarlarıyla ilgili farkındalığın arttığını ve etkenin doğru saptanarak uygun tanı/tedavi süreçleri uygulanması durumunda prognozda iyileşme sağlanabildiğini vurgulamaktadır.

\section{ÇIKAR ÇATIŞMASI}

Yazarlar bu makale ile ilgili herhangi bir çıkar çatışması bildirmemişlerdir.

\section{KAYNAKLAR}

1. Seidel D, Duran Graeff LA, Vehreschild M, Wisplinghoff H, Ziegler M, Vehreschild J], et al. FungiScopeGlobal emerging fungal infection registry. Mycoses 2017; 60(8): 508-16.

2. Nucci M, Marr KA, Vehreschild MJ, de Souza CA, Velasco E,Cappellano P, et al. Improvement in the outcome of invasive Fusariosis in the last decade. Clin Microbiol Infect 2014; 20(6): 580-5.

3. Tortorano AM, Prigitano A, Esposto MC, Arsenijevic VA, Kalorovic J, Ivanovic D, et al. European Confederation of Medical Mycology (ECMM) epidemiological survey on invasive infections due to Fusarium species in Europe. Eur J Clin Microbiol Infect Dis 2014; 33(9): 1623-30.

4. Tortorano AM, Richardson M, Roilides E, van Diepeningen A, Caira M, Munoz P, et al. ESCMID and ECMM joint guidelines on diagnosis and management of Hyalohyphomycosis: Fusarium spp., Scedosporium spp. and others. Clin Microbiol Infect 2014; 20 (Suppl 327):- 46.

5. Chowdhary A, Meis JF, Guarro J, de Hoog GS, Kathuria S, Arendrup MC, et al. ESCMID and ECMM joint clinical guidelines for the diagnosis and management of systemic Phaeohyphomycosis: diseases caused by black fungi. Clin Microbiol Infect 2014; 20 (Suppl 347): 75.

6. Hoenigl M, Salmanton Garcia J, Walsh TJ, Nucci M, Neoh CH, Jenks JD, et al. Global guideline for the diagnosis and management of rare mould infections: an initiative of the European Confederation of Medical Mycology in cooperation with the International Society for Human and Animal Mycology and the American Society for Microbiology. Lancet Infect Dis 2021; 21(8): e246-e257.

7. Richter R, Erbakan N. [Current status of medical mycology in Turkey]. Mycopathol Mycol Appl 1958; 10(1): 41-52.

8. Gülmez D, Sığ AK, Akar N, Duyan S, Arıkan Akdağlı S. [Changing trends in isolation frequencies and species of clinical fungal strains: what do the 12-years (2008-2019) mycology laboratory data tell about?]. Mikrobiyol Bul 2021; 55(1): 53-66.

9. Gülmez D, Alp Ş. Mantar infeksiyonlarının laboratuvar tanısında klasik yöntemler ve yeni gelişmeler. FLORA 2021; 26(1): 34-49.

10. Page MJ, McKenzie JE, Bossuyt PM, Boutron I, Hoffmann TC, Mulrow CD, et al. The PRISMA 2020 statement: an updated guideline for reporting systematic reviews. BMJ 2021; 372n71.

11. Hoffman JJ, Burton MJ, Leck A. Mycotic keratitis-a global threat from the filamentous fungi. J Fungi (Basel) 2021; 7(4): 273.

12. Yücel A. Scedosporium apiospermum (Monosporium apiospermum)'dan ileri gelen bir göz mikozu. Turk Mikrobiyol Cemiy Derg 1989; 19(1): 25-9.

13. Şili U, Bilgin H, Masania R, Eryüksel E, Cimşit NC, Ayrancı G, et al. Successful treatment of an invasive fungal infection caused by Talaromyces sp. with voriconazole. Med Mycol Case Rep 2015; 821-3.

14. Ersal T, Al Hatmi AS, Cilo BD, Curfs Breuker I, Meis JF, Özkalemkaş F, et al. Fatal disseminated infection with Fusarium petroliphilum. Mycopathologia 2015; 179(1-2): 119-24.

15. Kantarcıoğlu AS, Summerbell RC, Sutton DA, Yücel A, Sarıkaya E, Kaner G, et al. A dark strain in the Fusarium $\checkmark$ species complex isolated from primary subcutaneous sporotrichioid lesions associated with traumatic inoculation via a rose bush thorn. Med Mycol 2010; 48(1): 103-9. 
16. Doymaz MZ, Seyithanoğlu MF, Hakyemez I, Gültepe BS, Çevik S, Aslan T. A case of cerebral Phaeohyphomycosis caused by Fonsecaea monophora, a neurotropic dematiaceous fungus, and a review of the literature. Mycoses 2015; 58(3): 187-92.

17. Dalyan Cilo B, Al Hatmi AM, Seyedmousavi S, Rijs AJMM, Verweij PE, Ener B, Emergence of fusarioses in a university hospital in Turkey during a 20-year period. Eur J Clin Microbiol Infect Dis 2015; 34(8): 1683-91.

18. Özyurt M, Ardıç N, Turan K, Yıldız Ş, Özyaral O, Demirpek U, et al. The isolation of Fusarium sporotrichioides from a diabetic foot wound sample and identification. Marmara Medical Journal 2008; 21(1): 68-72.

19. Efe Iris N, Güvenç S, Özçelik T, Demiral A, Koçulu S, Çevik E, et al. Successful treatment of disseminated Fusariosis with the combination of voriconazole and liposomal amphotericin B. Turk J Haematol 2016; 33(4): 363-4.

20. Barış A, Öncül A, Öztürk K, Barış A, Aykut S, Aktaş E. The importance of mycological diagnosis: A Scedosporium apiospermum complex mycetoma case neglected for 20 years. Mikrobiyol Bul 2021; 55(2): 256-64.

21. Akova Budak B, Baykara M, Kıvanç SA, Yılmaz H, Çiçek S. Comparing the ocular surface effects of topical vancomycin and linezolid for treating bacterial keratitis. Cutan Ocul Toxicol 2016; 35(2): 126-30.

22. Uludokumaci S, Balkan II, Mete B, Özaras R, Saltoğlu N, Soysal T. Ecthyma gangrenosum-like lesions in a febrile neutropenic patient with simultaneous Pseudomonas sepsis and disseminated Fusariosis. Turk J Haematol 2013; 30(3): 321-4.

23. Yıldıran ST, Kömürcü S, Saraçlı MA, Gönlüm A, Beyan C, Yalçın A. Fusarium fungaemia in severely neutropenic patients. Mycoses 1998; 41(11-12): 467-9.

24. Kiraz N, Uzun M, Ağırbaşlı H, Anğ Ö. Akut lösemili bir hastadan tanınan Acremonium suşu. Turk J Infect 1996; 10(1): 73-4.

25. Öztaş E, Ödemiş B, Kekilli M, Kurt M, Dinç BD, Parlak E, et al. Systemic Phaeohyphomycosis resembling primary sclerosing cholangitis caused by Exophiala dermatitidis. J Med Microbiol 2009; 58(Pt 9): 1243-6.

26. Alabaz D, Kibar F, Arıkan S, Sancak B, Çelik Ü, Aksaray N, et al. Systemic Phaeohyphomycosis due to Exophiala (Wangiella) in an immunocompetent child. Med Mycol 2009; 47(6): 653-7.

27. Kıratlı H, Uzun Ö, Kiraz N, Eldem B. Scedosporium apiospermum chorioretinitis. Acta Ophthalmol Scand $2001 ; 79(5): 540-2$.

28. Coşkun S, Balaban N, Kuştimur S, Sarıcaoğlu S, Özbek S, Çayırlı A, Acremonium spp. ile Pseudomonas mesophilica'nın sebep olduğu infektif keratit. Flora 2002; 7(4): 265-8.

29. Güngel H, Eren MH, Pınarcı EY, Altan Ç, Baylançiçek DO, Kara N, et al. An outbreak of Fusarium $v$ endophthalmitis after cataract surgery in an eye training and research hospital in Istanbul. Mycoses 2011; 54(6): e767-74.

30. Çakır M, İmamoğlu S, Çekiç O, Bozkurt E, Alagöz N, Öksüz L,et al. An outbreak of early-onset endophthalmitis caused by Fusarium species following cataract surgery. Curr Eye Res 2009; 34(11): 988-95.

31. Koç AN, Erkılıç K, Evrensel N, Coşkun A. A case of Alternaria keratitis treated with fluconazole. Eur J Clin Microbiol Infect Dis 1997; 16(4): 322-3.

32. Dursun Ö, Vatansever M, Dinç E, Bozkurt F. Alternaria alternata keratitli bir olgu. Turkiye Klinikleri J Ophthalmol 2017; 26(3): 223-6.

33. Adıbelli FM, Karabıçak N, Akal A, Göncü T, Yılmaz OF, Bayraktar M. Fonsecaea pedrosoi as a rare cause of acute conjunctival ulceration. Arq Bras Oftalmol 2016; 79(4): 261-3.

34. Ekmen H, Erbakan N. Miçetoma (Madura ayağı) Memleketimizde kültürel teşhisi yapılan 3 vak'a. Mikrobiyol Bul 1967; 1(3): 149-54.

35. Erbağcı Z, Tuncel AA, Erkılıç S, Zer Y. Successful treatment of antifungal- and cryotherapy-resistant subcutaneous Hyalohyphomycosis in an immunocompetent case with topical $5 \%$ imiquimod cream. Mycopathologia 2005; 159(4): 521-6.

36. Kantarcıoğlu AS, Yücel A. Cerrahpaşa Tıp Fakültesi Mikrobiyoloji ve Klinik Mikrobiyoloji Anabilim Dalı'nda tanımlanmış olan Pseudallescheriasis olguları ve Avrupa Tıp Mikolojisi Konfederasyonu (ECMM) Pseudallescheriasis çalışma grubu. Cerrahpaşa Tıp Derg 2005; 36(2): 90-6. 
37. Yücel A, Tuğrul M, Kantarcıoğlu AS, Aygıt C, Öğütlü A. Kemiği tutan bir infeksiyondan Scedosporium inflatum (Eşeyli şekli Pseudallescheria boydii)'un ayrıldığı bir olgu. Cerrahpaşa Tıp Derg 1998; 29(3): 145-7.

38. Erbağcı Z, Balcı i, Erkılıç S, Zer Y, İnci R. Cutaneous Hyalohyphomycosis and onychomycosis caused by Onychocola canadensis: report of the first case from Turkey. J Dermatol 2002; 29(8): 522-8.

39. Hilmioğlu S, Metin DY, Taşbakan M, Pullukçu H, Akalın T, Tumbay E. Skin infection on both legs caused by Acremonium strictum (case report). Ann Saudi Med 2015; 35(5): 406-8.

40. Karadağ AS, Cebeci F, Aslan Kayıran M, Özakkaş F, Çobanoğlu B, Kuru BC, et al. Fusarium v infection in a diabetic patient treated with itraconazole and debridement. Dermatol Ther 2020; 33(6): e14203.

41. Karaarslan A, Arıkan S, Karaarslan F, Çetin ES. Skin infection caused by Scedosporium apiospermum. Mycoses 2003; 46(11-12): 524-6.

42. Tural Kara T, Özdemir H, İnce E, İleri T, Çiftçi E. Fonsecaea pedrosoi: A rare cause of dental infection and maxillary osteomyelitis in a child with acute lymphoblastic leukemia. Turk J Pediatr 2016; 58(6): 679-82.

43. Artüz F, Allı N, Lenk N, Güngör E. Purple erythematous plaques on the face and left arm. Chromomycosis. Arch Dermatol 1997; 133(8): 1029-32.

44. Ünal A, Sipahioğlu MH, Atalay MA, Kavuncuoğlu F, Tokgöz B, Koç AN, et al. Tenckhoff catheter obstruction without peritonitis caused by Curvularia species. Mycoses 2011; 54(4): 363-4.

45. Öz Y, Kiraz N, Özkurt S, Soydan M. Colonization of peritoneal catheter with a thermophilic fungus, Thermoascus crustaceus: a case report. Med Mycol 2010; 48(8): 1105-7.

46. Uzunoğlu E, Şahin AM. Paecilomyces variotii peritonitis in a patient on continuous ambulatory peritoneal dialysis. J Mycol Med 2017; 27(2): 277-80.

47. Polat M, Kara SS, Tapısız A, Demirtaş Z, Sarı S, Kalkancı A, et al. Successful treatment of Paecilomyces variotii peritonitis in a liver transplant patient. Mycopathologia 2015; 179(3-4): 317-20.

48. Kendirli T, Çiftçi E, Ekim M, Galip N, Düzenli F, Özçakar ZB, et al. Acremonium spp. peritonitis in an infant. Mycoses 2008; 51(5): 455-7.

49. Şener AG, Yücesoy M, Şentürkün S, Afşar I, Yurtsever SG, Türk M. A case of Acremonium strictum peritonitis. Med Mycol 2008; 46(5): 495-7.

50. Keçeli S, Yeğenağa I, Dağdelen N, Üçkardeş H, Willke A. Case report: peritonitis by Penicillium spp. in a patient undergoing continuous ambulatory peritoneal dialysis. Int Urol Nephrol 2005; 37(1): 129-31.

51. Eşel D, Koç AN, Utaş C, Karaca N, Bozdemir N. Fatal peritonitis due to Trichoderma sp. in a patient undergoing continuous ambulatory peritoneal dialysis. Mycoses 2003; 46(1-2): 71-3.

52. Koç AN, Utaş C, Oymak O, Sehmen E. Peritonitis due to Acremonium strictum in a patient on continuous ambulatory peritoneal dialysis. Nephron 1998; 79(3): 357-8.

53. Ay Altıntop Y, Koç AN. A fatal Acremonium falciforme peritonitis. Med Science 2018; 7(1): 222-4.

54. Civelek R, Çakar MK, Yeğin ZA, Erbaş G, Tunçcan ÖG, Kalkancı A, et al. Acremonium potronii associated pneumonia in an allogenic stem cell transplantation recipient. GMJ 2016; 27(4): 203-4.

55. Koç AN, Mutlu Sarıgüzel F, Artış T. Pleuritis caused by Acremonium strictum in a patient with colon adenocarcinoma. Mycoses 2008; 51(6): 554-6.

56. Sav H, Altınbaş R, Beştepe Dursun Z. A fatal invasive Scedosporium apiospermum pulmonary infection in an adult patient with malignant lung adenocarcinoma. Curr Med Mycol 2020; 6(3): 61-4.

57. Atalay A, Koç AN, Akyol G, Çakır N, Kaynar L, Kılıç Ulu A. Pulmonary infection caused by Talaromyces purpurogenus in a patient with multiple myeloma. Infez Med 2016; 24(2): 153-7.

58. Ergin C, Kutlu M, Arıkan Akdağli S,Sarıbaş Z, Ozansoy FA, Sarı I, et al. Isolation of Scedosporium apiospermum (teleomorph: Pseudallescheria apiosperma) from an acute myeloid leukemia patient. Mikrobiyol Bul 2013; 47(2): 351-5.

59. Kanlıoğlu Kuman N, Pabuşçu E, Özkütük A, Gültekin B, Şen S. Scedosporium colonization in surgically treated bronchiectasis: case report. Türkiye Klinikleri Arch Lung 2013; 14(1): 11-3. 
60. Palaoğlu S, Sav A, Başak T, Yalçınlar Y, Scheithauer BW. Cerebral Phaeohyphomycosis. Neurosurgery 1993; 33(5): 894-7.

61. Kantarcıoğlu AS, Guarro J, de Hoog GS, Apaydın H, Kiraz N, Balkan ii, et al. A case of central nervous system infection due to Cladophialophora bantiana. Rev Iberoam Micol 2016; 33(4): 237-41.

62. Atalay MA, Koç AN, Koyuncu S,Ulu Kılıç A, Kurtsoy A, Meşe EA.Cladophilaphora bantiana brain abscess treated with voriconazole in an immunocompetent patient. Mikrobiyol Bul 2014; 48(3): 501-6.

63. Alpaydın S, Güler A, Çelebisoy N, Hilmioğlu Polat S, Turhan T. Pseudallescheria boydii infection of the central nervous system: first reported case from Turkey. Acta Neurol Belg 2015; 115(3): 489-92. 


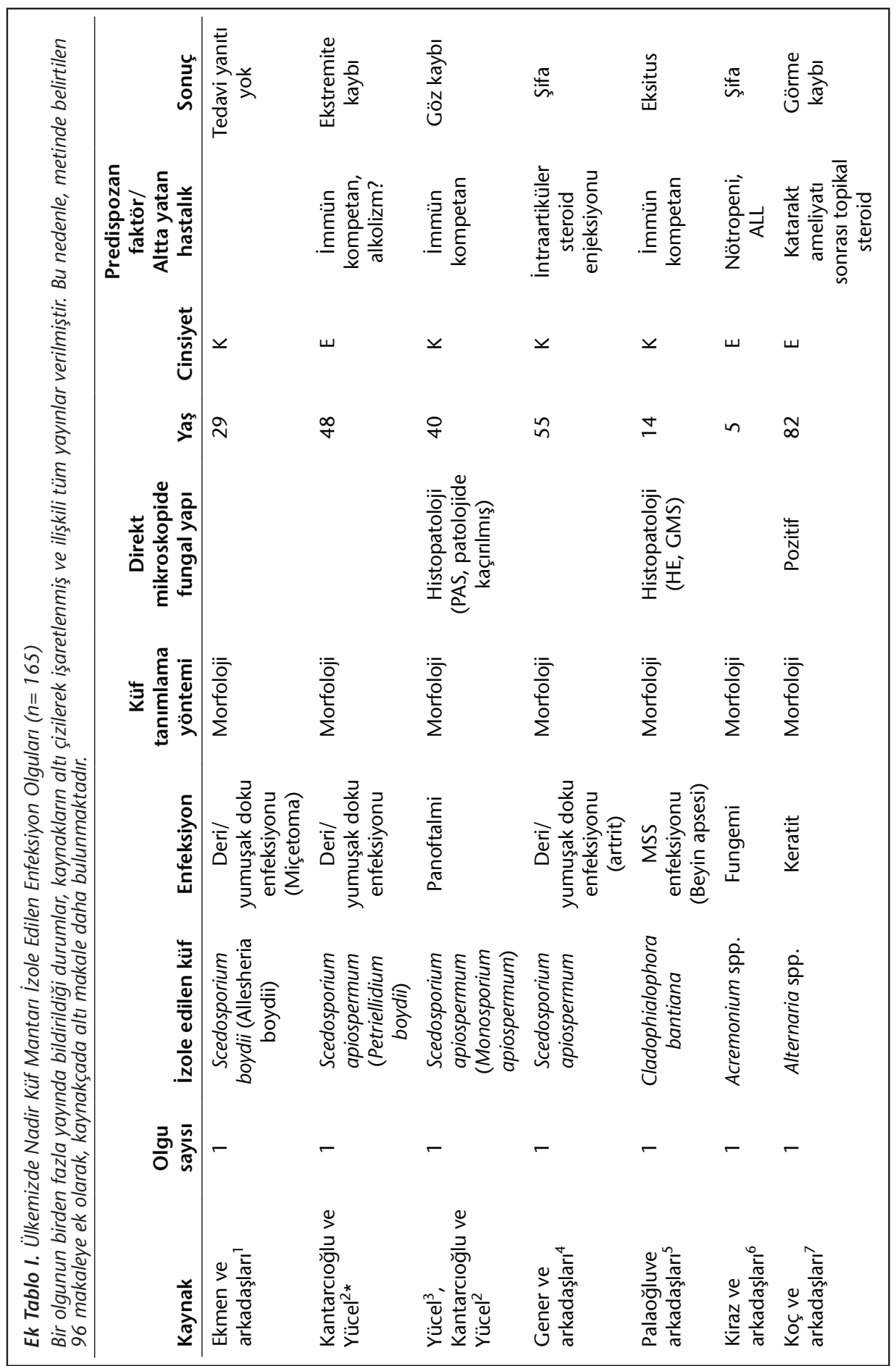




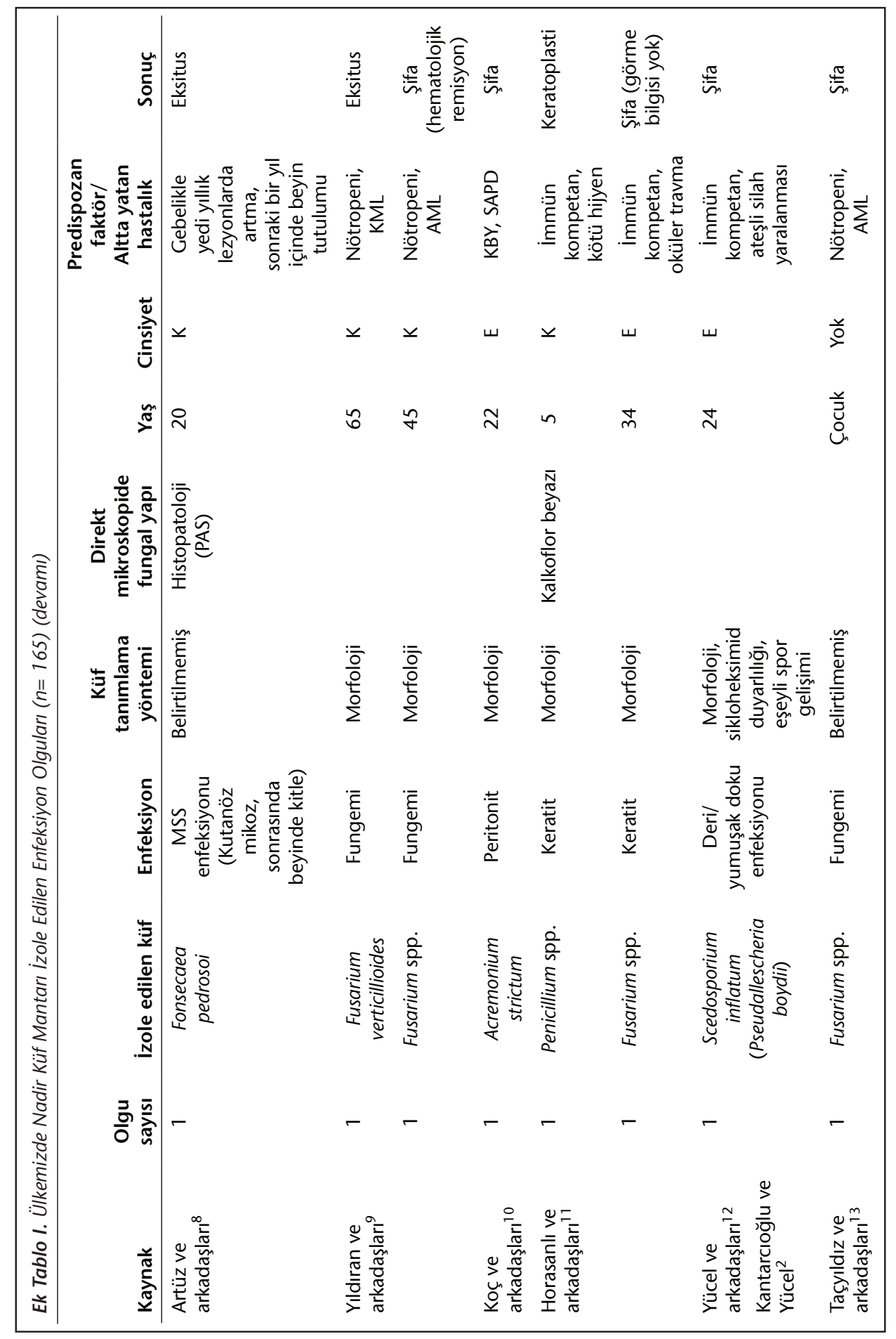




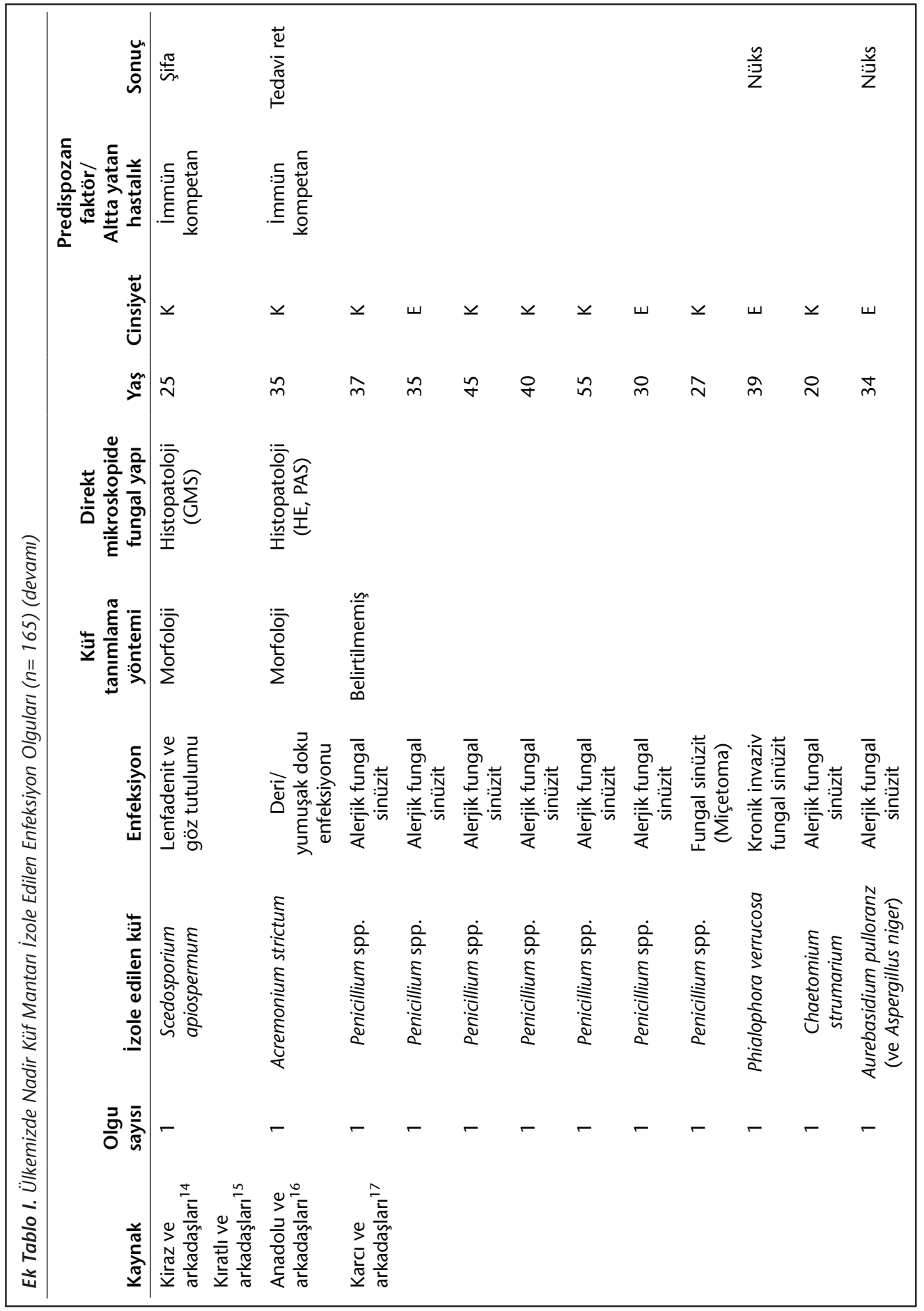




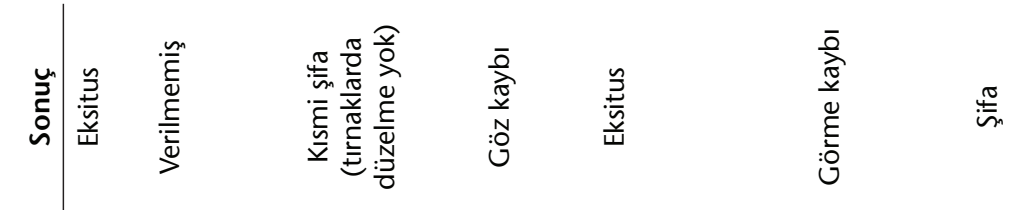

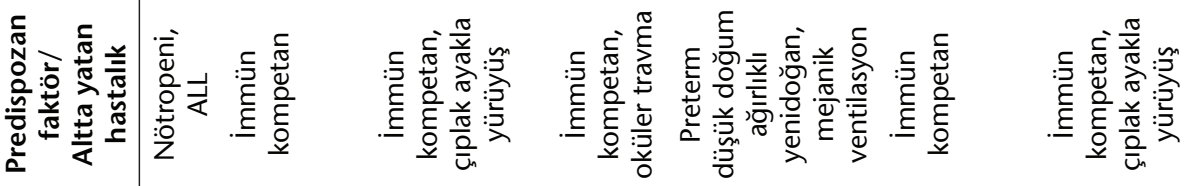

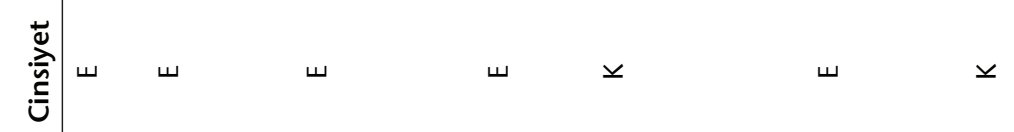

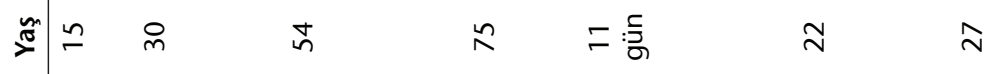

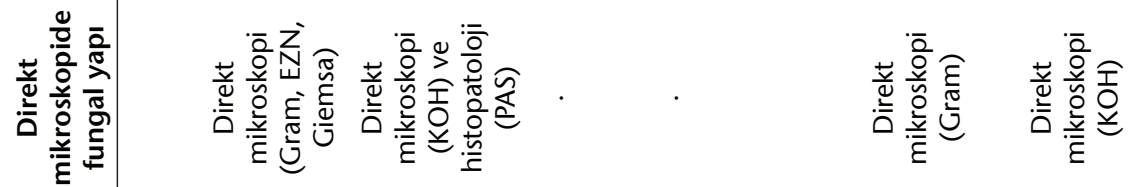

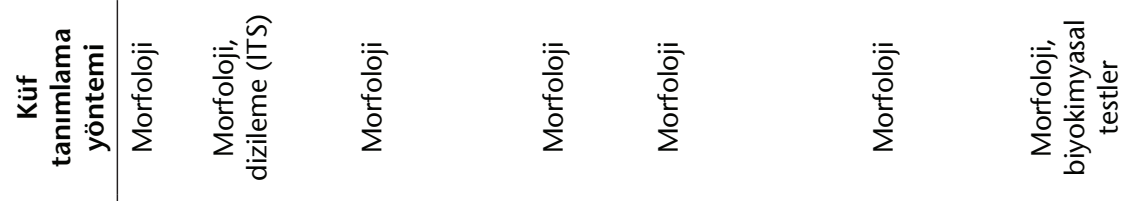

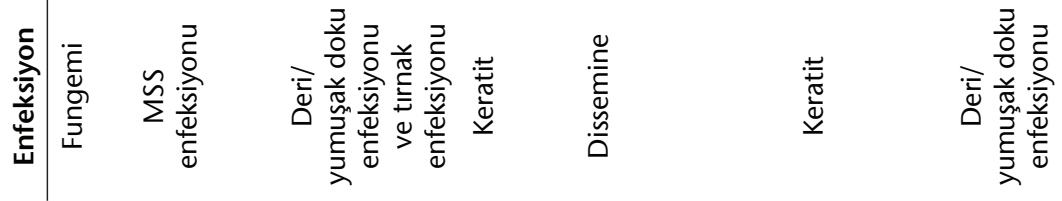

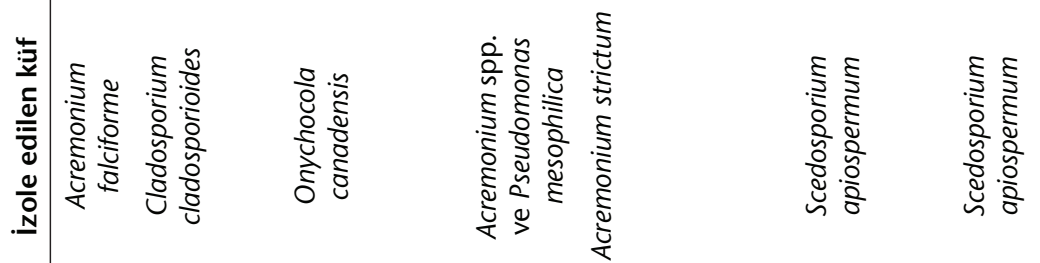

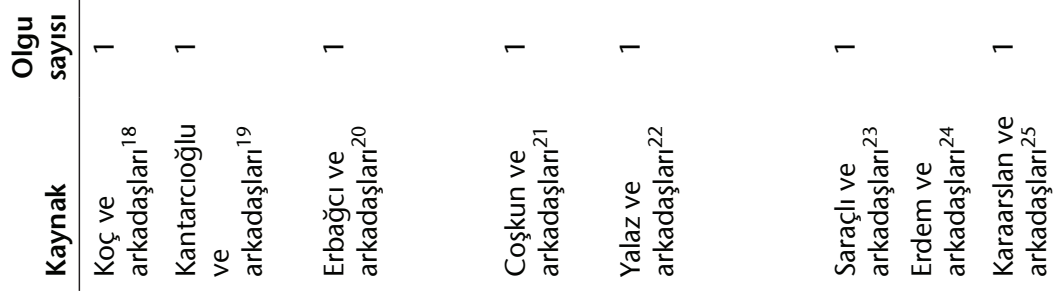




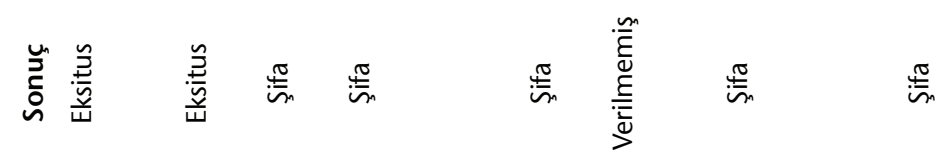

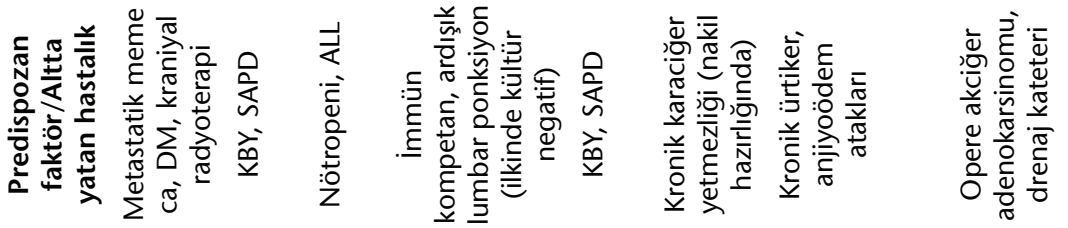

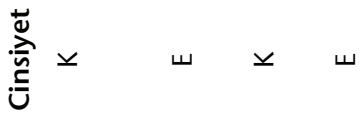

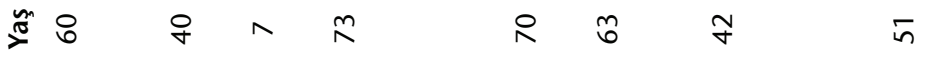

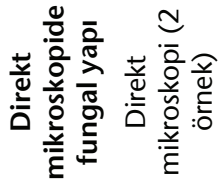

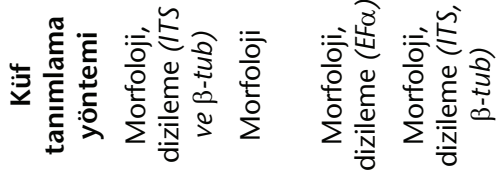

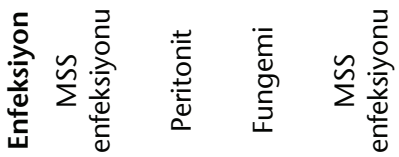

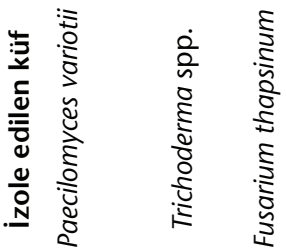

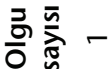

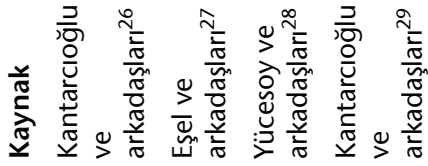

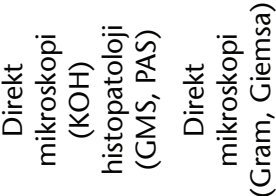

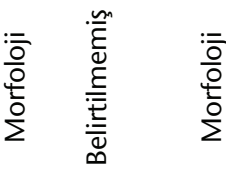

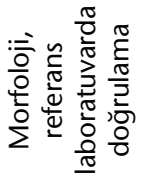

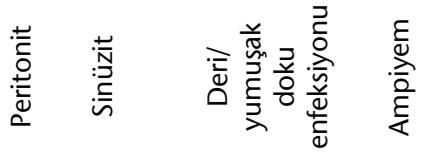

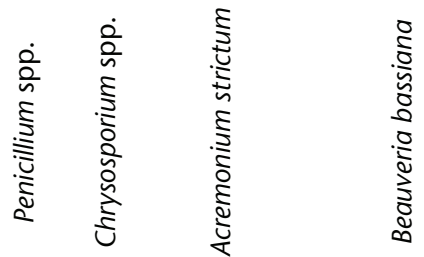




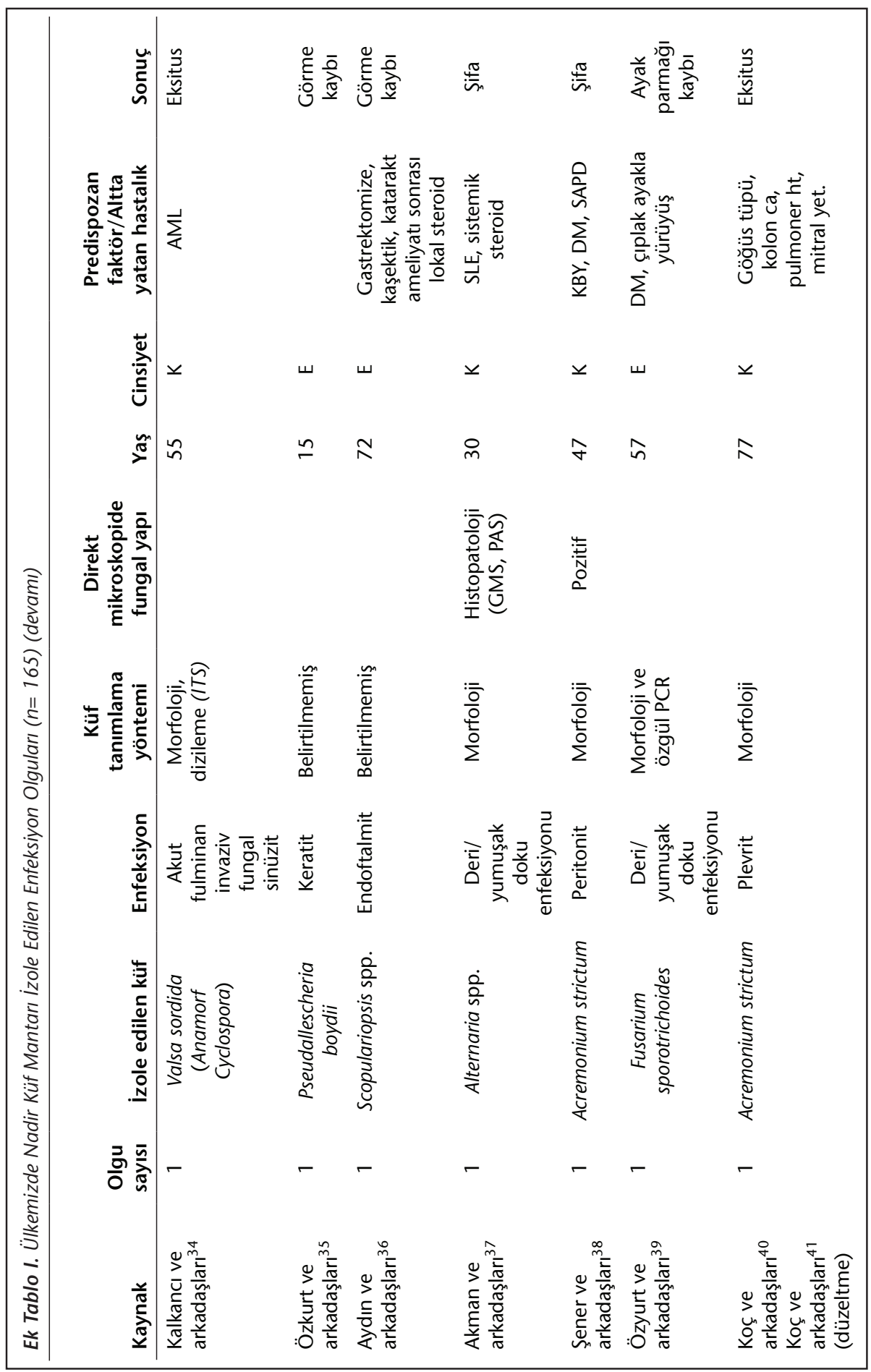




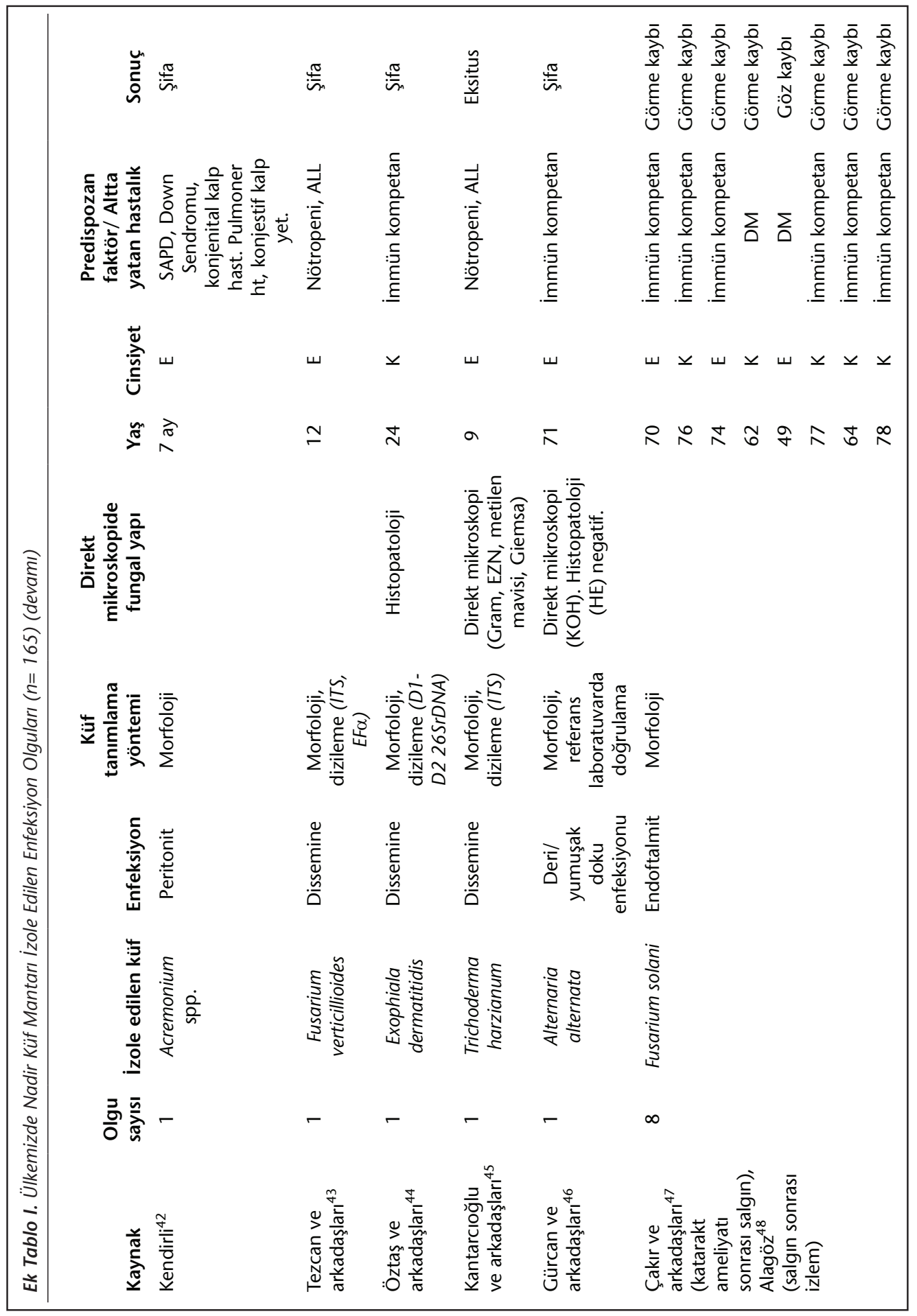




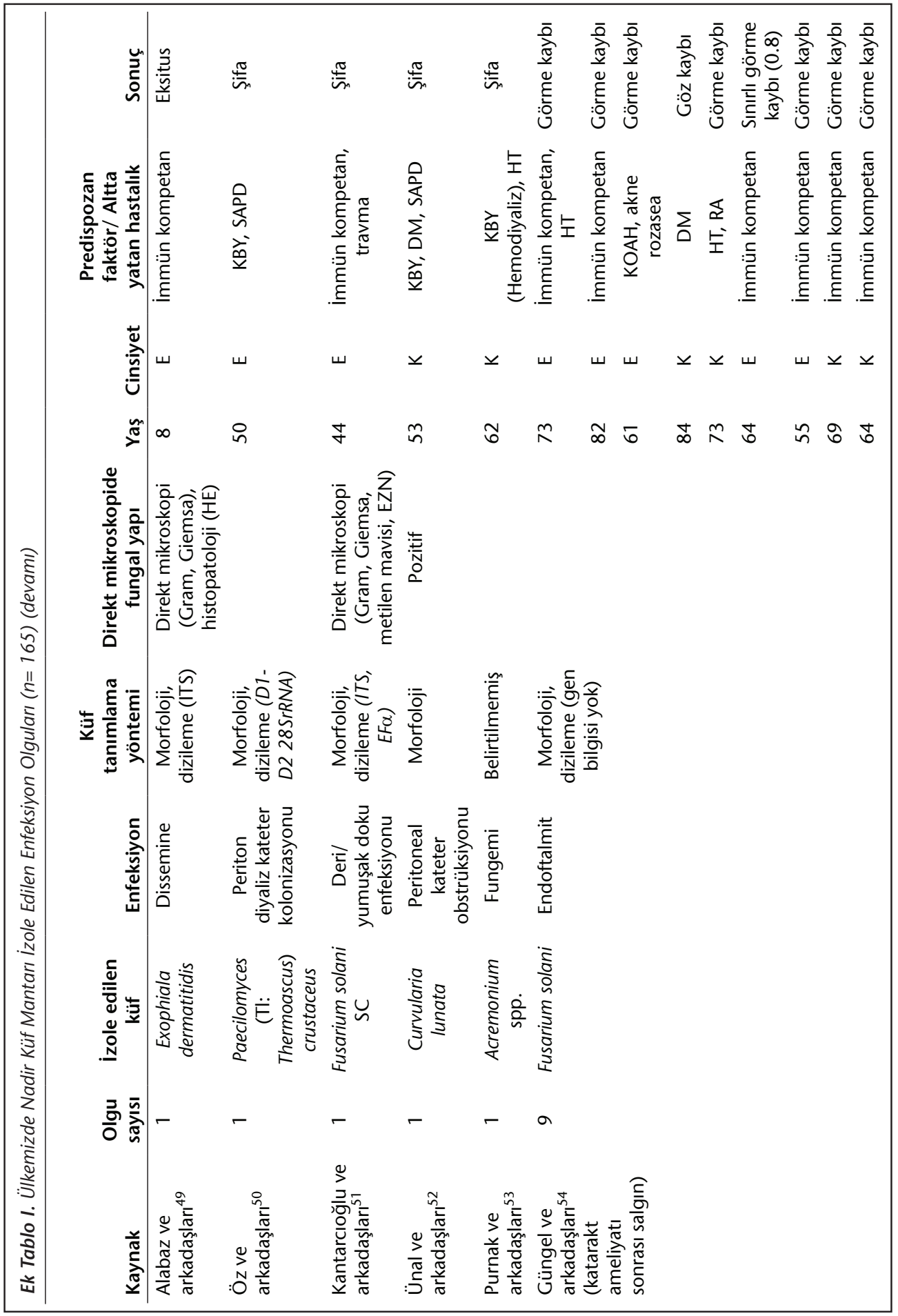




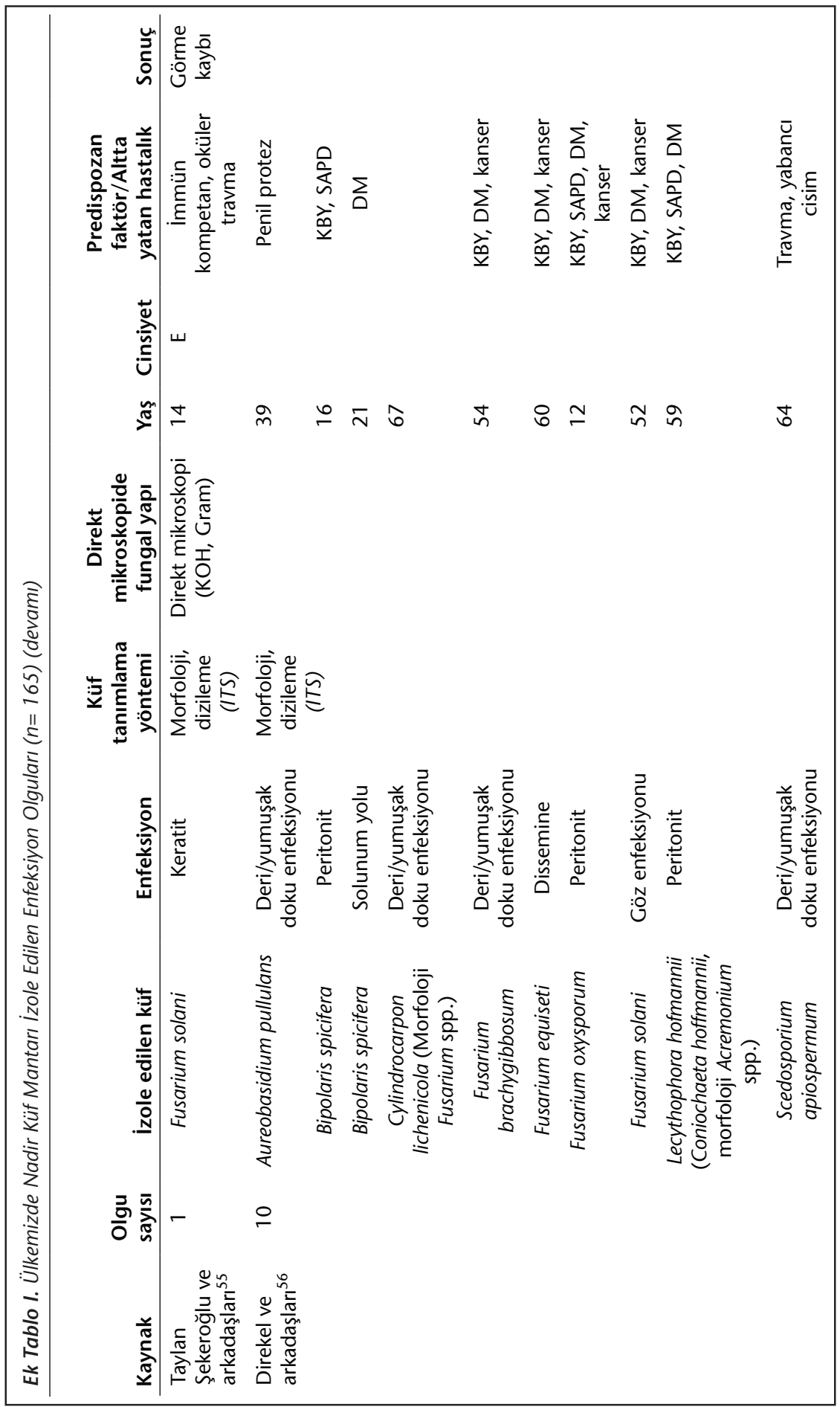




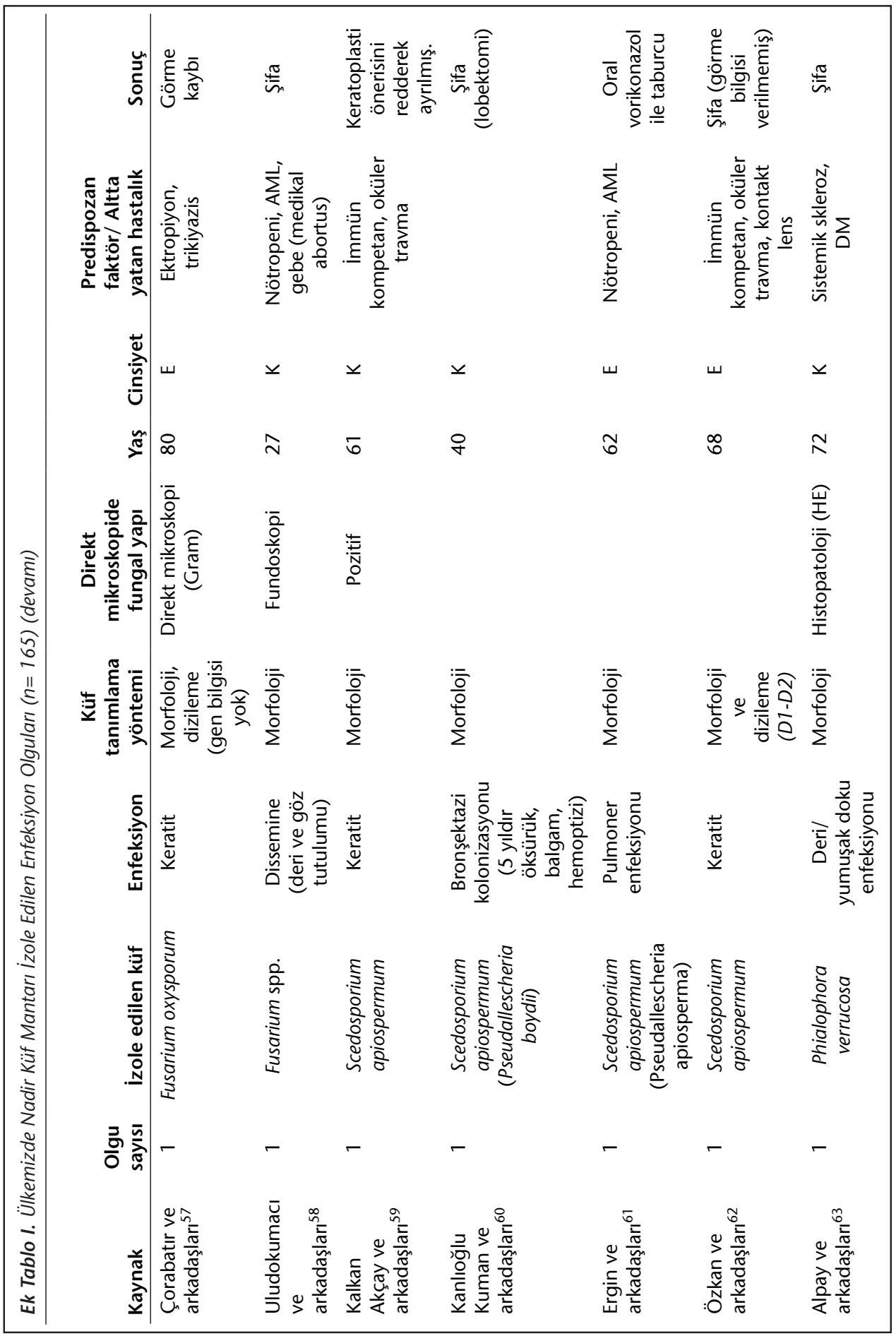




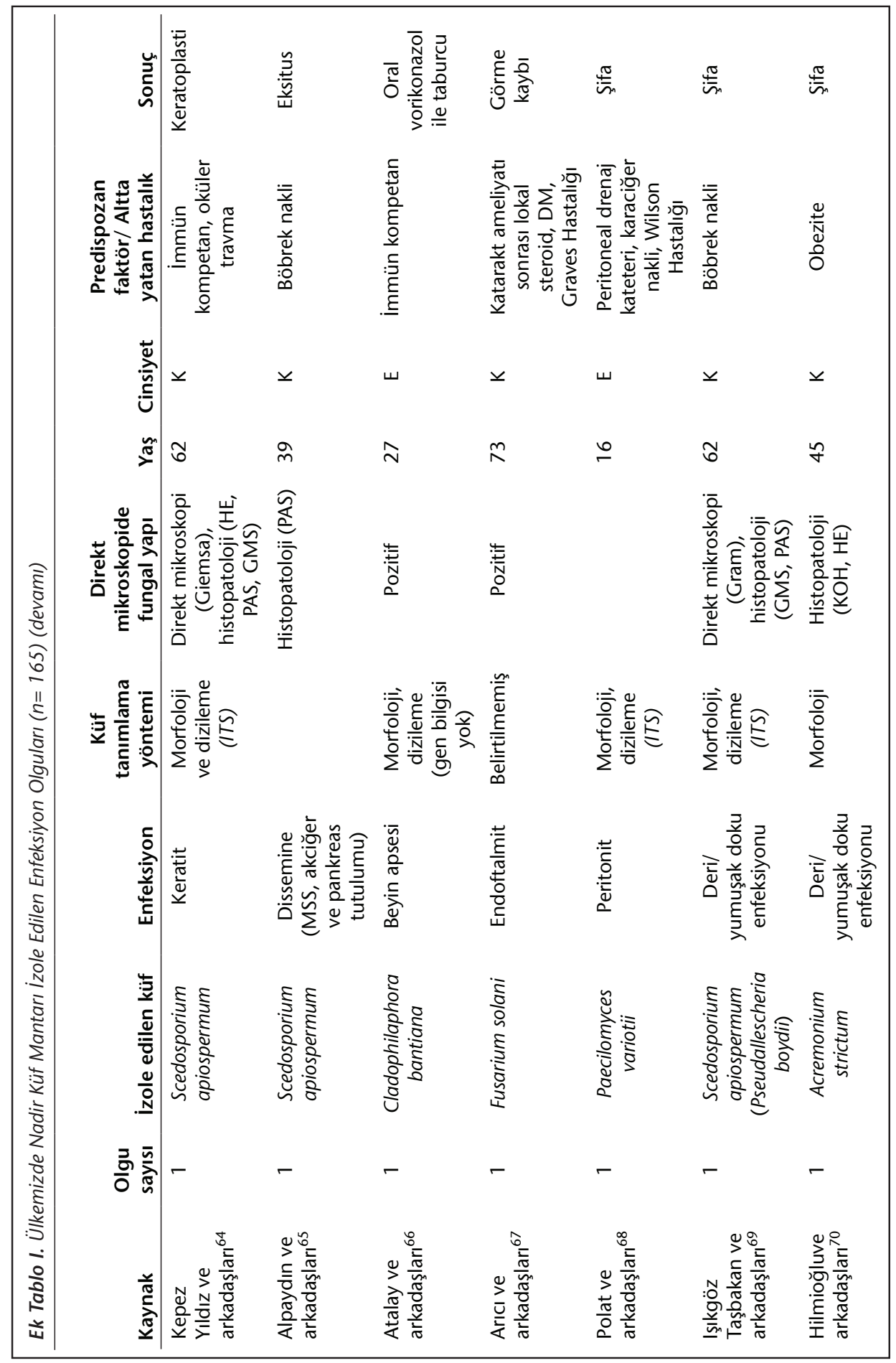




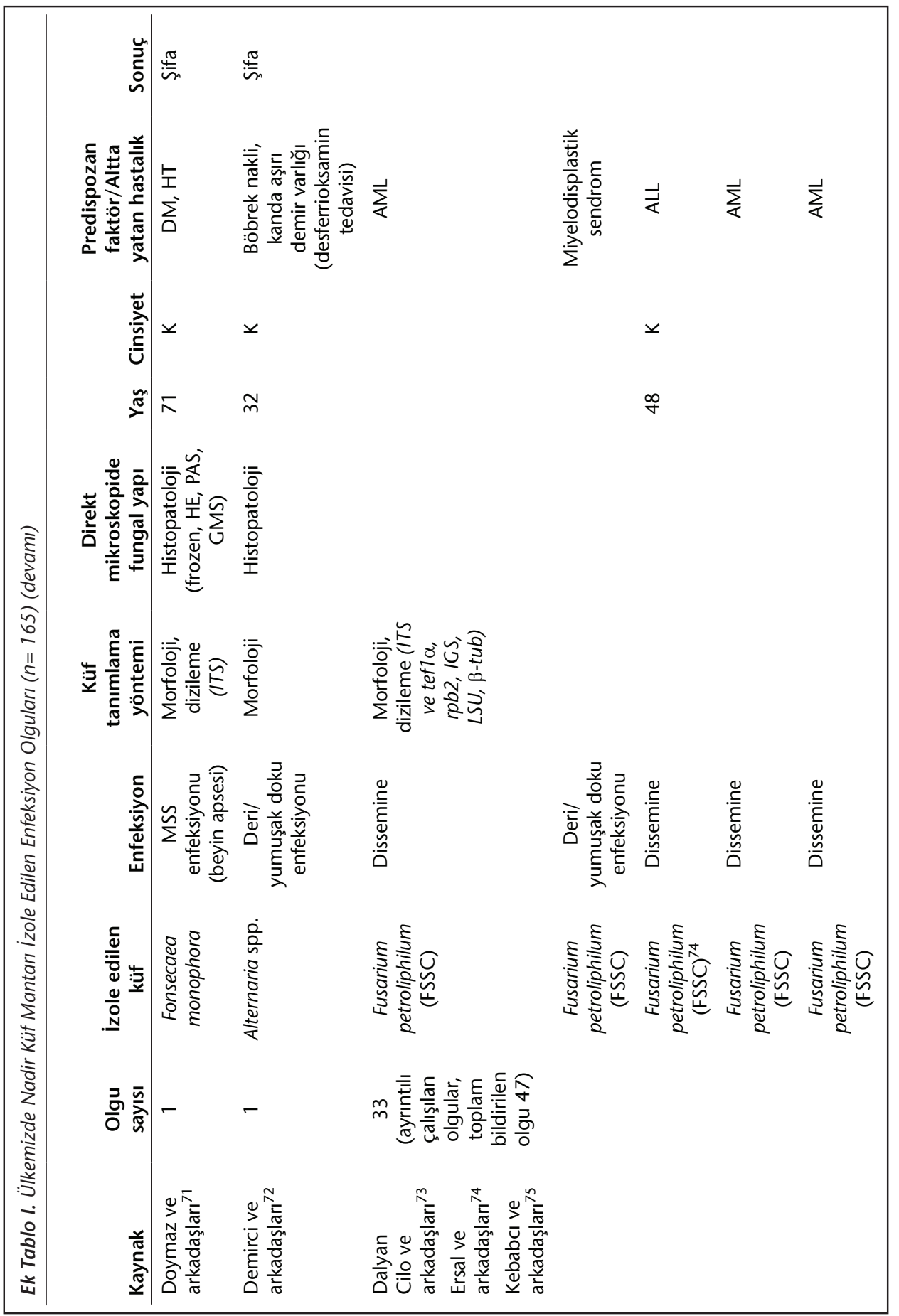




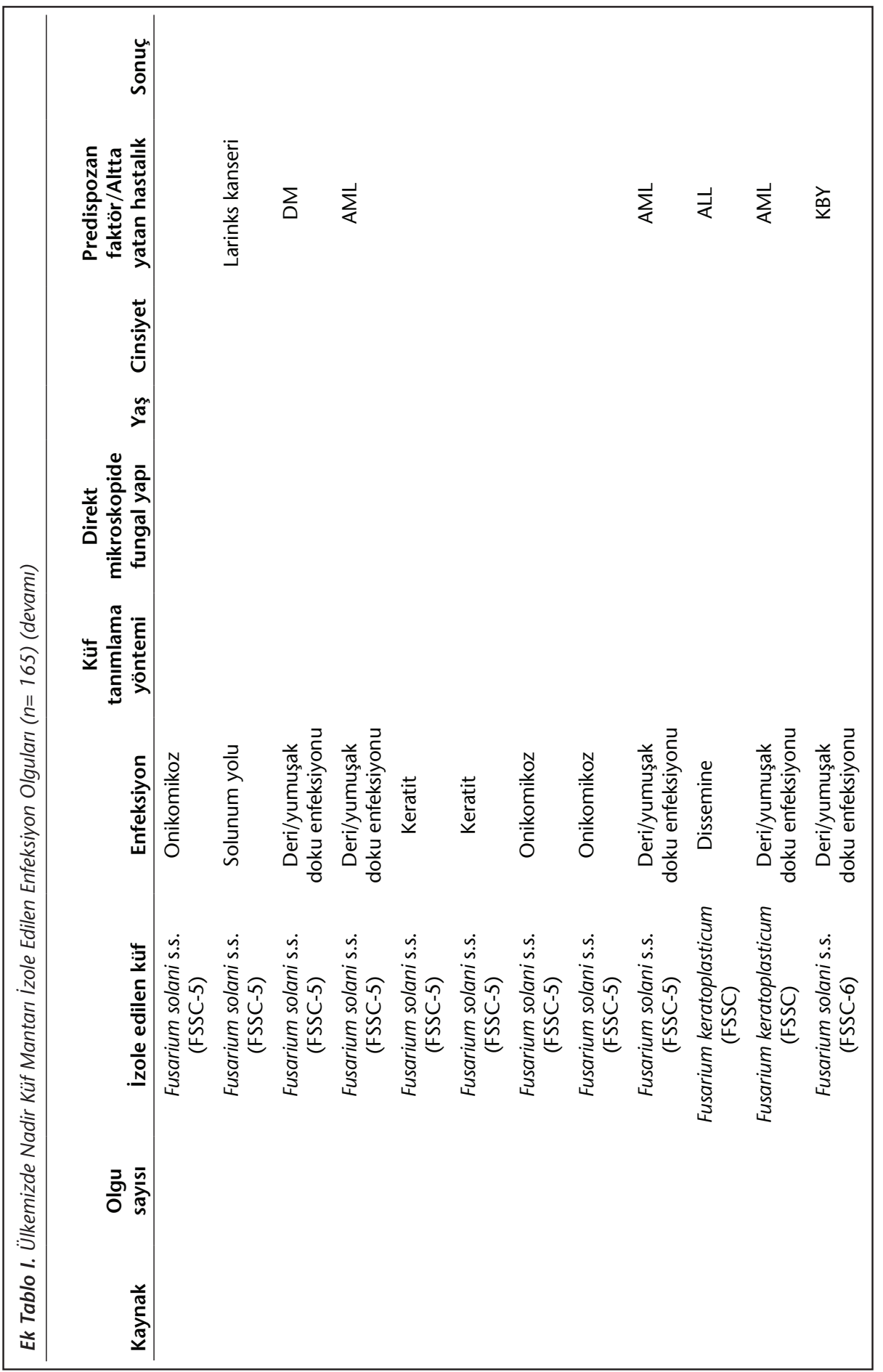




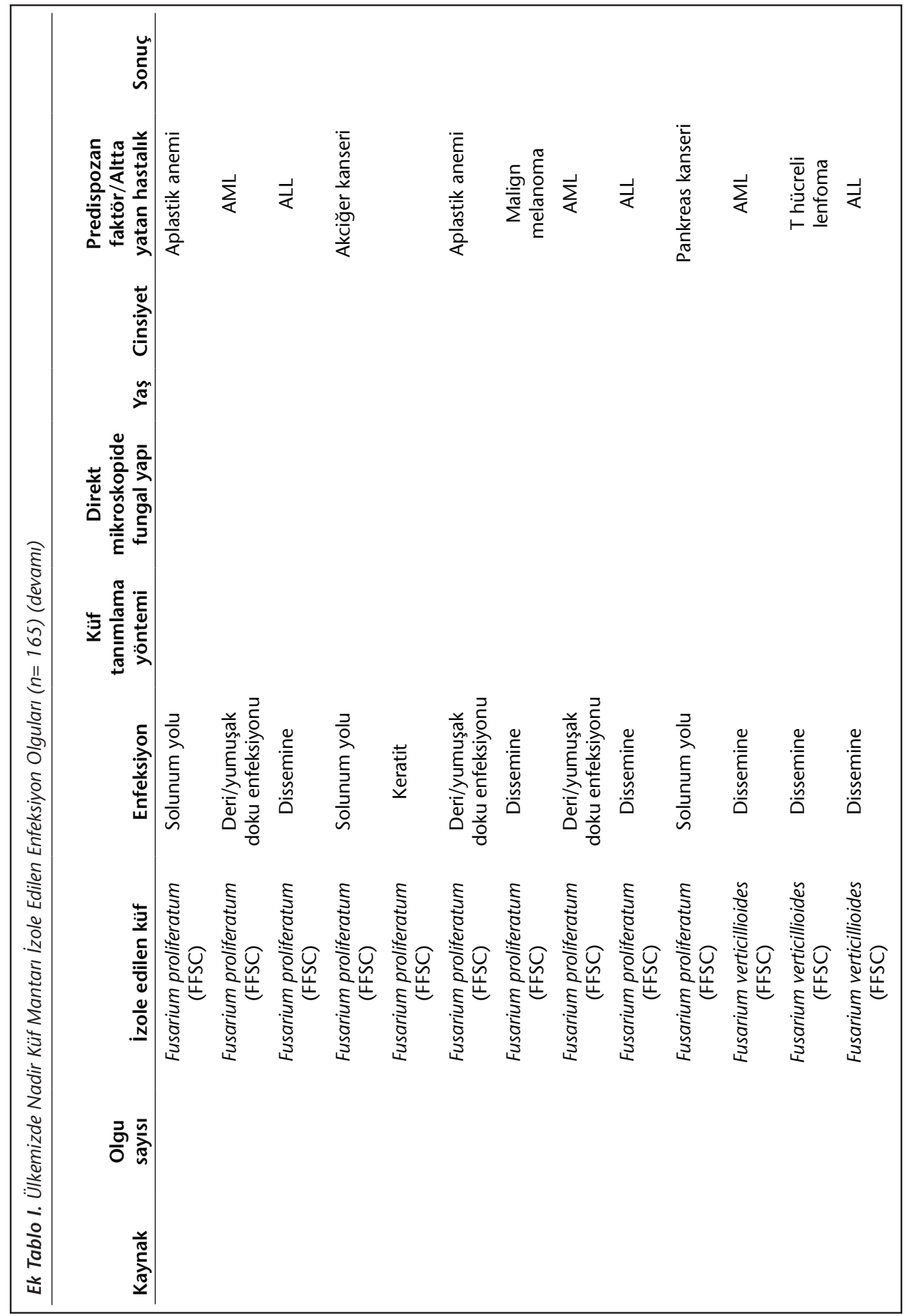




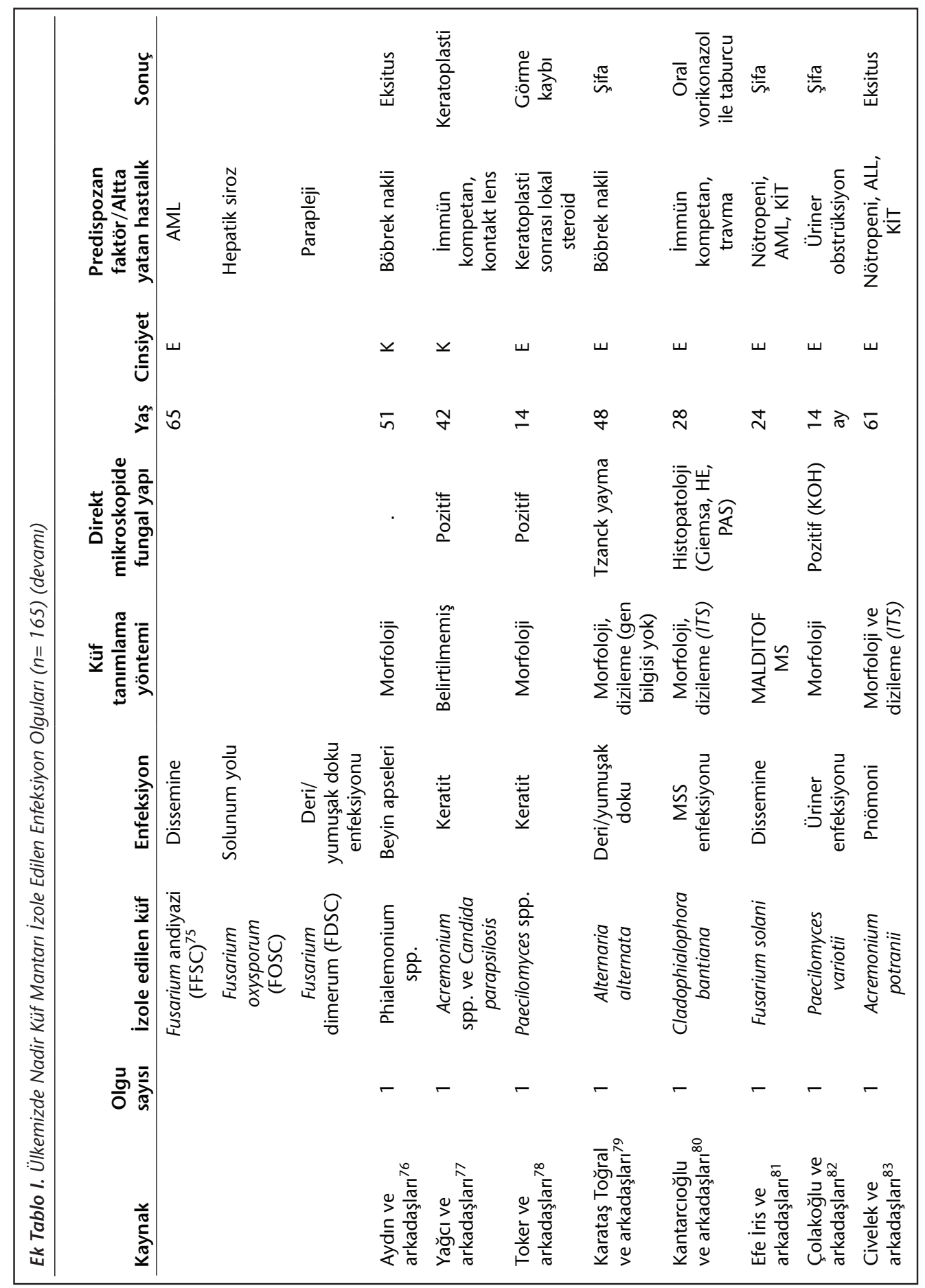




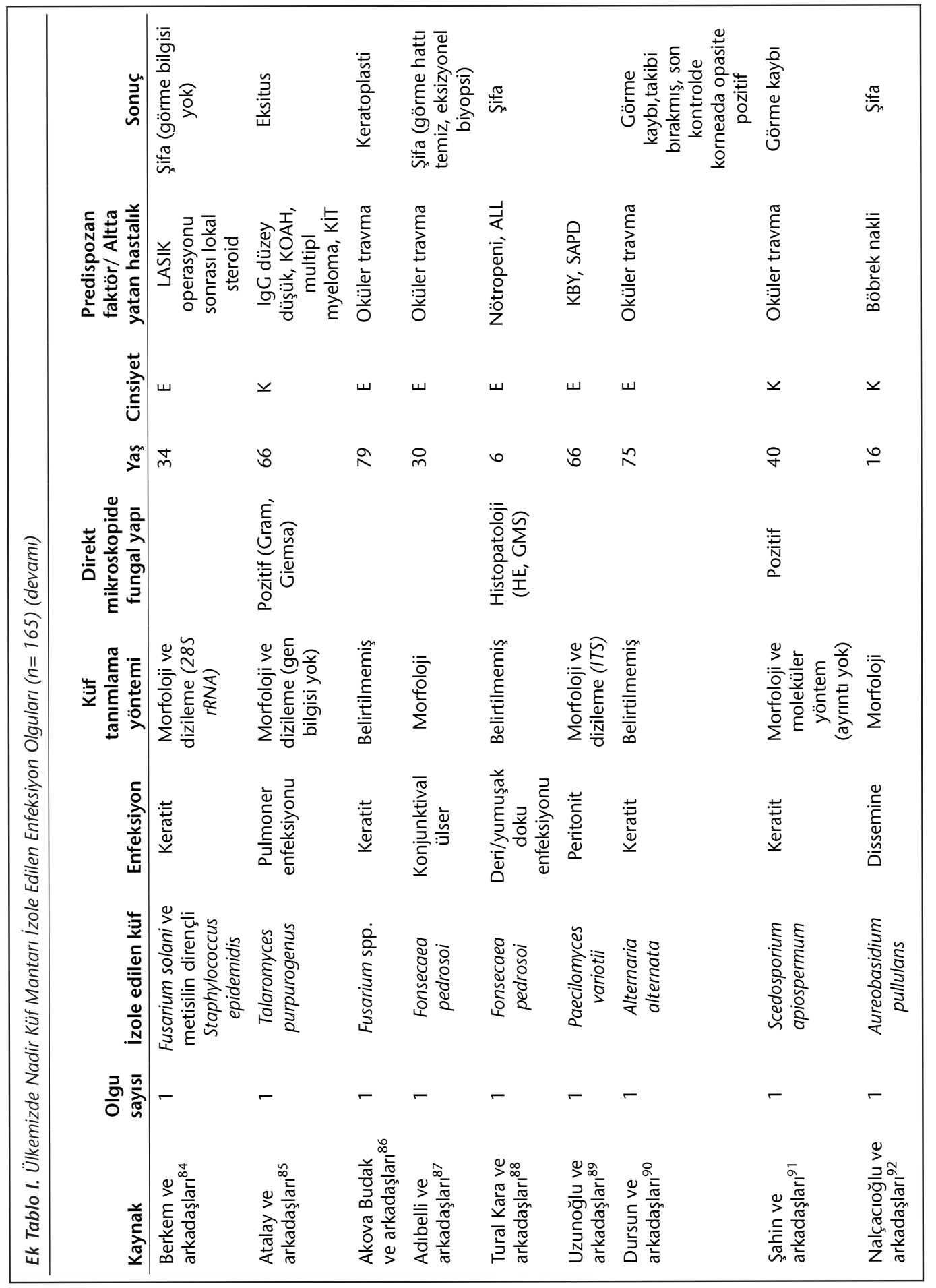




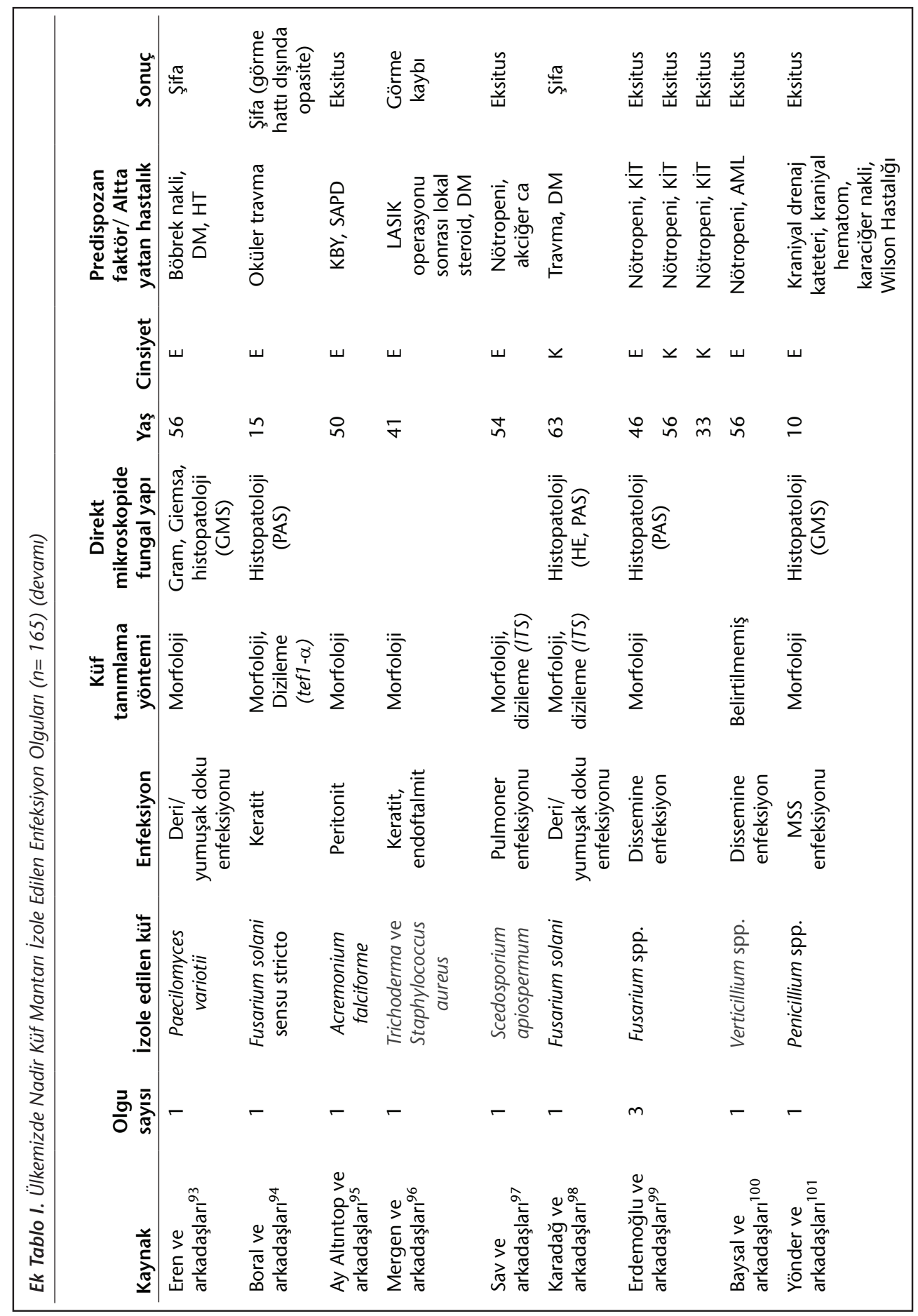




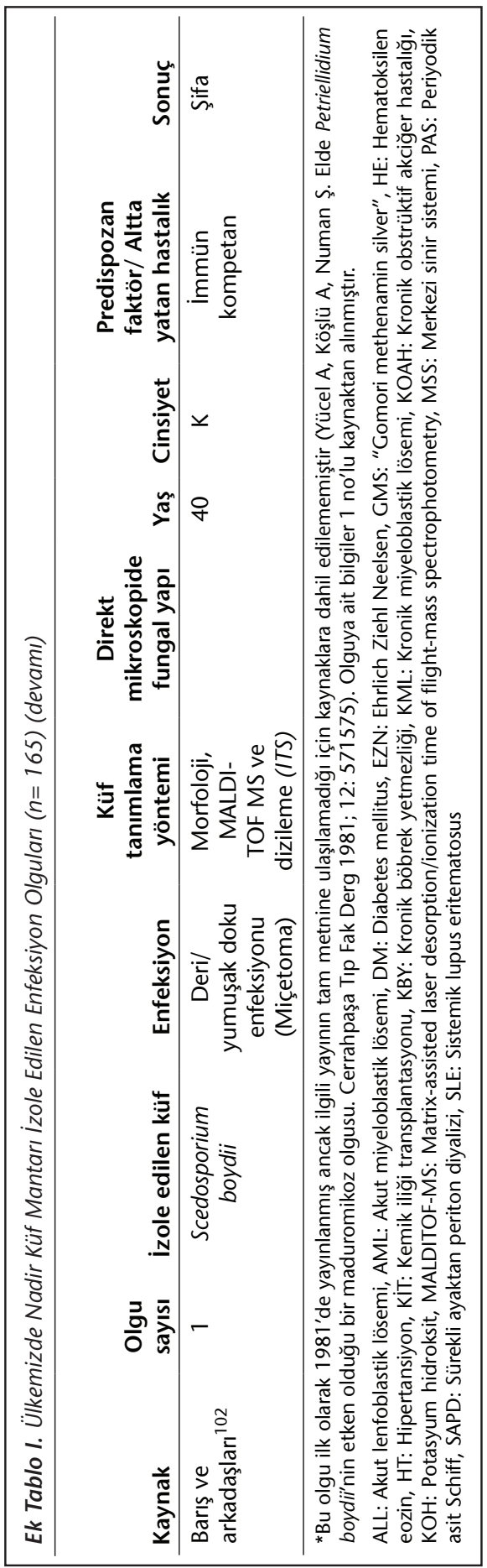




\section{EK 1 KAYNAKLAR}

1. Ekmen H, Erbakan N. Miçetoma (Madura ayağı) Memleketimizde kültürel teşhisi yapılan 3 vak'a. Mikrobiyol Bul 1967; 1(3): 149-54.

2. Kantarcıoğlu AS, Yücel A. Cerrahpaşa Tıp Fakültesi Mikrobiyoloji ve Klinik Mikrobiyoloji Anabilim Dalı́nda tanımlanmış olan Pseudallescheriasis olguları ve Avrupa Tıp Mikolojisi Konfederasyonu (ECMM) Pseudallescheriasis çalışma grubu. Cerrahpasa Tıp Derg 2005; 36(2): 90-6.

3. Yücel A. Scedosporium apiospermum (Monosporium apiospermum)'dan ileri gelen bir göz mikozu. Türk Mikrobiyol Cemiy Derg 1989; 19(1): 25-9.

4. Gener FA, Kuştimur S, Sultan N, Sever A. Fungal arthritis due to Scedosporium apiospermum (Pseudoallescheria boydii) Z Rheumatol 1991; 50(4): 219-21.

5. Palaoğlu S, Sav A, Başak T, Yalçınlar Y, Scheithauer BW. Cerebral phaeohyphomycosis. Neurosurgery 1993; 33(5): 894-7.

6. Kiraz N, Uzun M, Ağırbaşlı H, Anğ Ö. Akut lösemili bir hastadan tanınan Acremonium suşu. Turk J Infect 1996; 10(1): 73-4.

7. Koç AN, Erkılıç K, Evrensel N, Coşkun A. A case of Alternaria keratitis treated with fluconazole. Eur J Clin Microbiol Infect Dis 1997; 16(4): 322-3.

8. Artüz F, Allı N, Lenk N, Güngör E. Purple erythematous plaques on the face and left arm. Chromomycosis. Arch Dermatol 1997; 133(8): 1029, 32.

9. Yıldıran ST, Kömürcü S, Saraçlı MA, Gönlüm A, Beyan C, Yalçın A. Fusarium fungaemia in severely neutropenic patients. Mycoses 1998; 41(11-12): 467-9.

10. Koç AN, Utaş C, Oymak O, Sehmen E. Peritonitis due to Acremonium strictum in a patient on continuous ambulatory peritoneal dialysis. Nephron 1998; 79(3): 357-8.

11. Horasanlı S, Erturan Z, Kiraz M, Eroğlu F, Gürler N. Fusarium ve Penicillium cinsi mantarların etken olduğu iki kornea apsesi olgusu. Turk J Infect 1998; 12(3): 427-32.

12. Yücel A, Tuğrul M, Kantarcıoğlu AS, Aygıt C, Öğütlü A. Kemiği tutan bir infeksiyondan Scedosporium inflatum (Eşeyli şekli Pseudallescheria boydii)’un ayrıldığı bir olgu. Cerrahpasa Tip Derg 1998; 29(3): 145-7.

13. Taçyıldız N, Yavuz G, Ünal E, Gözdasoğlu S, Ertem M, Aysev D. Fungal infection from Fusarium spp. in children with refractory hematologic malignancies. Med Pediatr Oncol 1999; 33(6): 596-7.

14. Kiraz N, Gülbaş Z, Akgün Y, Uzun O. Lymphadenitis caused by Scedosporium apiospermum in an immunocompetent patient. Clin Infect Dis 2001; 32(3): E59-61.

15. Kıratlı H, Uzun Ö, Kiraz N, Eldem B. Scedosporium apiospermum chorioretinitis. Acta Ophthalmol Scand $2001 ; 79(5): 540-2$.

16. Anadolu R, Hilmioğlu S, Oskay T, Boyvat A, Peksari Y, Gürgey E. Indolent Acremonium strictum infection in an immunocompetent patient. Int J Dermatol 2001; 40(7): 451-3.

17. Karcı B, Burhanoğlu D, Erdem T, Hilmioğlu S, İnci R, Veral A. Fungal infections of the paranasal sinuses. Rev Laryngol Otol Rhinol (Bord) 2001; 122(1): 31-5.

18. Koç AN, Erdem F, Patıroğlu T. Case Report. Acremonium falciforme fungemia in a patient with acute leukaemia. Mycoses 2002; 45(5-6): 202-3.

19. Kantarcıoğlu AS, Yücel A, de Hoog GS. Isolation of Cladosporium cladosporioides from cerebrospinal fluid. Mycoses 2002; 45(11-12): 500-3.

20. Erbağcı Z, Balcı i, Erkılıç S, Zer Y, İnci R. Cutaneous hyalohyphomycosis and onychomycosis caused by Onychocola canadensis: report of the first case from Turkey. J Dermatol 2002; 29(8): 522-8.

21. Coşkun S, Balaban N, Kuştimur S, Sarıcaoğlu S, Özbek S, Çayırlı A. Acremonium spp. ile Pseudomonas mesophilica'nın sebep olduğu infektif keratit . Flora 2002; 7(4): 265-8.

22. Yalaz M, Hilmioğlu S, Metin D, Akisu M, Nart D, Cestin H, et al. Fatal disseminated Acremonium strictum infection in a preterm newborn: a very rare cause of neonatal septicaemia. J Med Microbiol 2003; 52(Pt 9): 835-7. 
23. Saraçlı MA, Erdem U, Gönlüm A, Yıldıran ST. Scedosporium apiospermum keratitis treated with itraconazole. Med Mycol 2003; 41(2): 111-4.

24. Erdem Ü, Bağkesen H, Durukan AH, Saraçlı MA, Hürmeriç V, Bayraktar MZ. Total korneal erime ile seyreden mantar keratitli bir olgunun klinik izlemi. Gülhane Tıp Derg 2005; 47(2): 135-8.

25. Karaarslan A, Arıkan S, Karaarslan F, Çetin ES. Skin infection caused by Scedosporium apiospermum. Mycoses 2003; 46(11-12): 524-6.

26. Kantarcıoğlu AS, Hatemi G, Yücel A, De Hoog GS, Mandel NM. Paecilomyces variotii central nervous system infection in a patient with cancer. Mycoses 2003; 46(1-2): 45-50.

27. Eşel D, Koç AN, Utas C, Karaca N, Bozdemir N. Fatal peritonitis due to Trichoderma sp. in a patient undergoing continuous ambulatory peritoneal dialysis. Mycoses 2003; 46(1-2): 71-3.

28. Yücesoy M, Ergon MC, Ören H, Gülay Z. Bir Fusarium fungemisi. Mikrobiyol Bul 2004; 38(3): $265-71$.

29. Kantarcıoğlu AS, Apaydın H, Yücel A, de Hoog GS, Samson RA, Vural M, Özemekçi S. Central nervous system infection due to Penicillium chrysogenum. Mycoses 2004; 47(5-6): 242-8.

30. Keçeli S, Yeğenağa I, Dağdelen N, Mutlu B, Üçkardeş H, Wilke A. Case report: peritonitis by Penicillium spp. in a patient undergoing continuous ambulatory peritoneal dialysis. Int Urol Nephrol 2005; 37(1): 129-31.

31. Çevik B, Uslu Tutar N, Musapaşaoğlu H, Akkuzu G. Fungal sinüzitli bir olguda bilgisayarlı tomografi bulguları. KBB-Forum 2006; 5(1): 44-7.

32. Erbağcı Z, Tuncel AA, Erkılıç S, Zer Y. Successful treatment of antifungal- and cryotherapy-resistant subcutaneous hyalohyphomycosis in an immunocompetent case with topical $5 \%$ imiquimod cream. Mycopathologia 2005; 159(4): 521-6.

33. Gürcan S, Tuğrul HM, Yörük Y, Özer B, Tatman Otkun M, Otkun M. First case report of empyema caused by Beauveria bassiana. Mycoses 2006; 49(3): 246-8.

34. Kalkanci A, Kustimur S, Sucak GT, Şenol E, Sugita T, Adams G. Fulminating fungal sinusitis caused by Valsa sordida, a plant pathogen, in a patient immunocompromised by acute myeloid leukemia. Med Mycol 2006; 44(6): 531-9.

35. Özkurt Y, Oral Y, Külekci Z, Benzonana N, Ustaoğlu R, Doğan OK. Pseudallescheria boydii keratitis. J Ped Ophthal Strab 2006; 43(2): 114-5.

36. Aydın S, Ertuğrul B, Gültekin B, Uyar G, Kır E. Treatment of two postoperative endophthalmitis cases due to Aspergillus flavus and Scopulariopsis spp. with local and systemic antifungal therapy. BMC Infect Dis 2007; 787.

37. Akman A, Sakallı Cakcak D, Özhak Baysan B, Yazısız V, Terzioğlu E, Çiftçioğlu MA, Cutaneous alternariosis in a patient with systemic lupus erythematosus. Lupus 2007; 16(12): 993-6.

38. Şener AG, Yücesoy M, Şentürkün S, Afşar I, Yurtsever SG, Türk M. A case of Acremonium strictum peritonitis. Med Mycol 2008; 46(5): 495-7.

39. Özyurt M, Ardıç N, Turan K, Yıldız Ş, Özyaral O, Demirpek U, et al. The isolation of Fusarium sporotrichioides from a diabetic foot wound sample and identification. Marmara Medical Journal 2008; 21(1): 68-72.

40. Koç AN, Mutlu Sarıgüzel F, Artış T. Pleuritis caused by Acremonium strictum in a patient with colon adenocarcinoma. Mycoses 2008; 51(6): 554-6.

41. Koç AN, Mutlu Sarıgüzel F, Artış T. Isolation of Acremonium strictum from pleural fluid of a patient with colon adenocarcinoma. Mycoses 2009; 52(2): 190-2.

42. Kendirli T, Çiftçi E, Ekim M, Galip N, Düzenli F, Özçakar ZB, et al. Acremonium spp. peritonitis in an infant. Mycoses 2008; 51(5): 455-7.

43. Tezcan G, Özhak Baysan B, Alastruey Izquierdo A, Öğünç D, Öngüt G, Yıldıran ŞT et al. Disseminated fusariosis caused by Fusarium verticillioides in an acute lymphoblastic leukemia patient after allogeneic hematopoietic stem cell transplantation. J Clin Microbiol 2009; 47(1): 278-81.

44. Öztaş E, Ödemiş B, Kekilli M, Kurt M, Dinç BM, Parlak E, et al. Systemic phaeohyphomycosis resembling primary sclerosing cholangitis caused by Exophiala dermatitidis. J Med Microbiol 2009; 58(Pt 9): $1243-6$. 
45. Kantarcıoğlu AS, Celkan T, Yücel A, Mikami Y, Kuruğoğlu S, Mitani H, et al. Fatal Trichoderma harzianum infection in a leukemic pediatric patient. Med Mycol 2009; 47(2): 207-15.

46. Gürcan S, Pişkin S, Kılıç H, Temelli BA, Yalçın O. Cutaneous infection caused by Alternaria alternata in an immunocompetent host. Mikrobiyol Bul 2009; 43(1): 163-7.

47. Çakır M, İmamoğlu S, Çekiç O, Bozkurt E, Alagöz N, Öksüz L, et al. An outbreak of early-onset endophthalmitis caused by Fusarium species following cataract surgery. Curr Eye Res 2009; 34(11): 988-95.

48. Alagöz N. Ten years after an outbreak of Fusarium endophthalmitis following cataract surgery. Arq Bras Oftalmol 2020; 83(5): 454-6.

49. Alabaz D, Kibar F, Arıkan S, Sancak B, Çelik Ü, Aksaray N,Turgut M. Systemic phaeohyphomycosis due to Exophiala (Wangiella) in an immunocompetent child. Med Mycol 2009; 47(6): 653-7.

50. Öz Y, Kiraz N, Özkurt S, Soydan M. Colonization of peritoneal catheter with a thermophilic fungus, Thermoascus crustaceus: a case report. Med Mycol 2010; 48(8): 1105-7.

51. Kantarcıoğlu AS, Summerbell RC, Sutton DA, Yücel A, Sarkaya E, Kaner G, et al. A dark strain in the Fusarium solani species complex isolated from primary subcutaneous sporotrichioid lesions associated with traumatic inoculation via a rose bush thorn. Med Mycol 2010; 48(1): 103-9.

52. Ünal A, Sipahioğlu MH, Atalay MA, Kavuncuoğlu F, Tokgöz B, Koç AN, et al. Tenckhoff catheter obstruction without peritonitis caused by Curvularia species. Mycoses 2011; 54(4): 363-4.

53. Purnak T, Beyazıt Y, Şahin GO, Shorbagi A, Akova M. A novel fungal pathogen under the spotlight-Acremonium spp. associated fungaemia in an immunocompetent host. Mycoses 2011; 54(1): 78-80.

54. Güngel H, Eren MH, Pınarcı EY, Altan Ç, Baylançiçek DO, Kara N, et al. An outbreak of Fusarium solani endophthalmitis after cataract surgery in an eye training and research hospital in Istanbul. Mycoses 2011; 54(6): e767-74.

55. Taylan Şekeroğlu H, Erdem E, Yağmur M, Gümral M, Ersöz R, Illkit M, et al. Successful medical management of recalcitrant Fusarium solani keratitis: molecular identification and susceptibility patterns. Mycopathologia 2012; 174(3): 233-7.

56. Direkel S, Otağ F, Aslan G, Ülger M, Emekdaş G. Identification of filamentous fungi isolated from clinical samples by two different methods and their susceptibility results. Mikrobiyol Bul 2012; 46(1): 65-78.

57. Çorabatır C, Ülger M, Yıldırım Ö, Kuş N, Otağ F. Korneal abse kültüründen Fusarium oxysporum izole edilen olgu. Mersin Üniv Sağlık Bilim Derg 2013; 6(1): 26-9.

58. Uludokumacı S, Balkan II, Mete B, Özaras R, Saltoğlu N, Soysal T. Ecthyma gangrenosum-like lesions in a febrile neutropenic patient with simultaneous Pseudomonas sepsis and disseminated fusariosis. Turk J Haematol 2013; 30(3): 321-4.

59. Kalkan Akçay E, Acıkgöz ZC, Can ME,Çelikbilek N, Can Dereli G, Çağıl N. Fungal keratitis caused by Scedosporium apiospermum: first report from Turkey. Mikrobiyol Bul 2013; 47(4): 727-33.

60. Kanlıoğlu Kuman N, Pabuş̧̧u E, Özkütük A, Gültekin B, Şen S. Scedosporium colonization in surgically treated bronchiectasis: case report. Turkiye Klinikleri Arch Lung 2013; 14(1): 11-3.

61. Ergin C, Kutlu M, Arıkan Akdağlı S, Sarıbaş Z, Aydeniz Ozansoy F, Sarı I, et al. Isolation of Scedosporium apiospermum (teleomorph: Pseudallescheria apiosperma) from an acute myeloid leukemia patient. Mikrobiyol Bul 2013; 47(2): 351-5.

62. Özkan A, Susever S, Erturan Z, Uzun M, Alparslan N, Öz Y, et al. A case of keratitis caused by Scedosporium apiospermum. JMID 2013; 3(1): 45-8.

63. Alpay A, Solak Tekin N, Cömert F, Koca R, Çınar S. Phialophora verrucosa'nın etken olduğu bir feohifomikoz olgusu. Türkiye Klinikleri J Dermatol 2013; 23(1): 12-6.

64. Kepez Yıldız B, Hasanreisoğlu M, Aktaş Z, Aksu G, Cömert Koçak B, Akata F. Fungal keratitis secondary to Scedosporium apiospermum infection and successful treatment with surgical and medical intervention. Int Ophthalmol 2014; 34(2): 305-8.

65. Alpaydın S, Güler A, Çelebisoy N, Hilmioğlu Polat S, Turhan T. Pseudallescheria boydii infection of the central nervous system: first reported case from Turkey. Acta Neurol Belg 2015; 115(3): 489-92. 
66. Atalay MA, Koç AN, Koyuncu S, Ulu Kılıç A, Kurtsoy A, Alp Meşe E. Cladophilaphora bantiana brain abscess treated with voriconazole in an immunocompetent patient. Mikrobiyol Bul 2014; 48(3): 501-6.

67. Arıcı C, Atalay E, Mangan MS, Kılıç B. Acute Fusarium solani endophthalmitis secondary to keratitis following cataract surgery. JCRO 2014; 2(3): 63-7.

68. Polat M, Kara SS, Tapısız A, Demirtaş Z, Sarı S, Kalkancı A, et al. Successful treatment of Paecilomyces variotii peritonitis in a liver transplant patient. Mycopathologia 2015; 179(3-4): 317-20.

69. Işıkgöz Taşbakan M, Önal U, Metin DY, Pallukçu H, Yamazsan T, Çeltik A, et al. A rare cause of soft tissue infections: Pseudallescheria boydii. JMID 2015; 5(4): 176-9.

70. Hilmioğlu S, Metin DY, Tasbakan M, Pallukçu H, Akalın T, Tümbay E. Skin infection on both legs caused by Acremonium strictum. Ann Saudi Med 2015; 35(5): 406-8.

71. Doymaz MZ, Seyithanoğlu MF, Hakyemez I, Gültepe BS, Çevik S, Aslan T. A case of cerebral phaeohyphomycosis caused by Fonsecaea monophora, a neurotropic dematiaceous fungus, and a review of the literature. Mycoses 2015; 58(3): 187-92.

72. Demirci M, Baran N, Üzüm A, Çallı Örgen A, Gül Yurtsever S, Demirdal T. Cutaneous Alternariasis in a patient with renal transplant. Jundishapur J Microbiol 2015; 8(5): e19082.

73. Dalyan Cilo B, Al Hatmi AM, Seyedmousavi S, Rijs AJMM, Verveij PE, Enar B, et al. Emergence of fusarioses in a university hospital in Turkey during a 20-year period. Eur J Clin Microbiol Infect Dis 2015; 34(8): $1683-91$.

74. Ersal T, Al Hatmi AS, Cilo BD, Curfs Breuker I, Meis JF, Özkalemkaş F, et al. Fatal disseminated infection with Fusarium petroliphilum. Mycopathologia 2015; 179(1-2): 119-24.

75. Kebabcı N, van Diepeningen AD, Ener B, Ersal T, Meijer M, Al Hatmi AMS, et al. Fatal breakthrough infection with Fusarium andiyazi: new multi-resistant aetiological agent cross-reacting with Aspergillus galactomannan enzyme immunoassay. Mycoses 2014; 57(4): 249-55.

76. Aydın M, Özçelik U, Çevik H, Çınar Ö, Evren E, Demirağ A. Multiple brain abscesses due to Phialemonium in a renal transplant recipient: first case report in the literature. Exp Clin Transplant 2015; (13 Suppl) 377-80.

77. Yağcı A, Palamar M, Polat Hilmioğlu S, İrkeç M. Cross-linking treatment and corneal transplant in refractory Acremonium keratitis: case report. Exp Clin Transplant 2016; 14(5): 580-3.

78. Toker E, Ziyade N, Atıcı S, Kepenkli Kadayıfçı E, Türel Ö, Toprak D, et al. Postoperative keratitis due to Paecilomyces: a rare pediatric case. Pan Afr Med J 2016; 24317.

79. Karataş Togral A, Güleç AT. Tzanck smear as an accurate and rapid diagnostic tool for cutaneous alternariosis in a renal transplant recipient. Clin Exp Dermatol 2016; 41(7): 747-50.

80. Kantarcıoğlu AS, Guarro J, de Hoog GS, Apaydın H, Kiraz N, İnanç Balkan I, et al. A case of central nervous system infection due to Cladophialophora bantiana. Rev Iberoam Micol 2016; 33(4): 237-41.

81. Efe Iris N, Güvenç S, Özçelik T, Demirel A, Koçulu S, Çevik E, et al. Successful treatment of disseminated fusariosis with the combination of voriconazole and liposomal amphotericin B. Turk J Haematol 2016; 33(4): 363-4.

82. Çolakoğlu S, Durmaz S, Poyrazoğlu H, Kasap Tekinsen FF, Atalay MA, Koç AN. Urinary system infection caused by Paecilomyces variotti. Eur J Gen Med 2016; 13(2): 168-70.

83. Civelek R, Çakar MK, Yeğin ZA, Erbaş G, Tunçcan ÖG, Kalkancı A, et al. Acremonium potronii associated pneumonia in an allogenic stem cell transplantation recipient. GMJ 2016; 27(4): 203-4.

84. Berkem R, Türkoğlu G, Yılmaz SE, Burcu A, Kalkancı A. Fusarium solani'nin etken olduğu fungal keratit olgusu. Flora 2016; 21(1): 33-7.

85. Atalay A, Koç AN, Akyol G, Çakır N, Kaynar L, Ulu Kılıç A. Pulmonary infection caused by Talaromyces purpurogenus in a patient with multiple myeloma. Infez Med 2016; 24(2): 153-7.

86. Akova Budak B, Baykara M, Kıvanç SA, Yılmaz H, Çiçek S. Comparing the ocular surface effects of topical vancomycin and linezolid for treating bacterial keratitis. Cutan Ocul Toxicol 2016; 35(2): 126-30.

87. Adıbelli FM, Karabıçak N, Akal A, Göncü T, Yılmaz ÖF, Bayraktar M. Fonsecaea pedrosoi as a rare cause of acute conjunctival ulceration. Arq Bras Oftalmol 2016; 79(4): 261-3. 
88. Tural Kara T, Özdemir H, İnce E, İleri T, Çiftçi E. Fonsecaea pedrosoi: a rare cause of dental infection and maxillary osteomyelitis in a child with acute lymphoblastic leukemia. Turk J Pediatr 2016; 58(6): 679-82.

89. Uzunoğlu E, Şahin AM. Paecilomyces variotii peritonitis in a patient on continuous ambulatory peritoneal dialysis. J Mycol Med 2017; 27(2): 277-80.

90. Dursun Ö, Vatansever M, Dinç E,Bozkurt F. Alternaria alternata keratitli bir olgu. Turkiye Klinikleri J Ophthalmol 2017; 26(3): 223-6.

91. Şahin G, Güler C, Özel Y, Yavuz MT. Nadir görülen fungal keratit etkeni Scedosporium apiospermum. MN Oftalmoloji 2018; 25(2): 124-7.

92. Nalçacıoğlu H, Yakupoğlu YK, Genç G, Belet N, Şensoy SG, Birinci A, et al. Disseminated fungal infection by Aureobasidium pullulans in a renal transplant recipient. Pediatr Transplant 2018; 22(3): e13152.

93. Eren D, Eroğlu E, Ulu Kılıç A, Atalay MA, Mumcu N, Sipahioğlu MH. Cutaneous ulcerations caused by Paecilomyces variotii in a renal transplant recipient. Transpl Infect Dis 2018; 20(3): e12871.

94. Boral H, van Diepeningen A, Erdem E, Yağmur M, de Hoog GS, Illkit M, et al. Mycotic keratitis caused by Fusarium solani sensu stricto (FSSC5): a case series. Mycopathologia 2018; 183(5): 835-40.

95. Ay Altıntop Y, Koç AN. A fatal Acremonium falciforme peritonitis. Med Science 2018; 7(1): 222-4.

96. Mergen B, Sarıcı AM, Baltu F, Bahar Tokman H, İskeleli G. Mixed keratitis caused by Trichoderma and methicillin-resistant Staphylococcus aureus after uneventful laser in situ keratomileusis. JCRO 2019; 7(1): 14-6.

97. Sav H, Altınbaş R, Beştepe Dursun Z. A fatal invasive Scedosporium apiospermum pulmonary infection in an adult patient with malignant lung adenocarcinoma. Curr Med Mycol 2020; 6(3): 61-4.

98. Karadağ AS, Cebeci F, Aslan Kayıran M, Özakkaş F, Çobanoğlu B, Kuru BC, et al. Fusarium solani infection in a diabetic patient treated with itraconazole and debridement. Dermatol Ther 2020; 33(6): e14203.

99. Erdemoğlu Y, Aydıngöz IE, Üstün C, Uzay A, Beşli Y, Öztürk Durmaz E, et al. Fusariosis manifesting as targetoid purpuric cutaneous lesions in immunocompromised patients. J Eur Acad Dermatol Venereol 2020; 34(11): e734-e6.

100. Baysal M, Ümit E, Özdöver AC, Kırizlar O, Demir AM. Invasive fungal infection with a rare organism in a patient with acute myeloid leukaemia. Natl Med J India 2020; 33(1): 22-3.

101. Yönder H, Akbulut S, Kocaaslan H, İnce V, Karadağ N, Demirtaş G, et al. Intracerebral hemorrhage related with Penicillium species following deceased-donor liver transplant. Exp Clin Transplant 2021; 19(1): 83-7.

102. Barış A, Öncül A, Öztürk K, Barış A, Aykut S, Aktaş E. The importance of mycological diagnosis: A Scedosporium apiospermum complex mycetoma case neglected for 20 years. Mikrobiyol Bul 2021; 55(2): 256-64. 


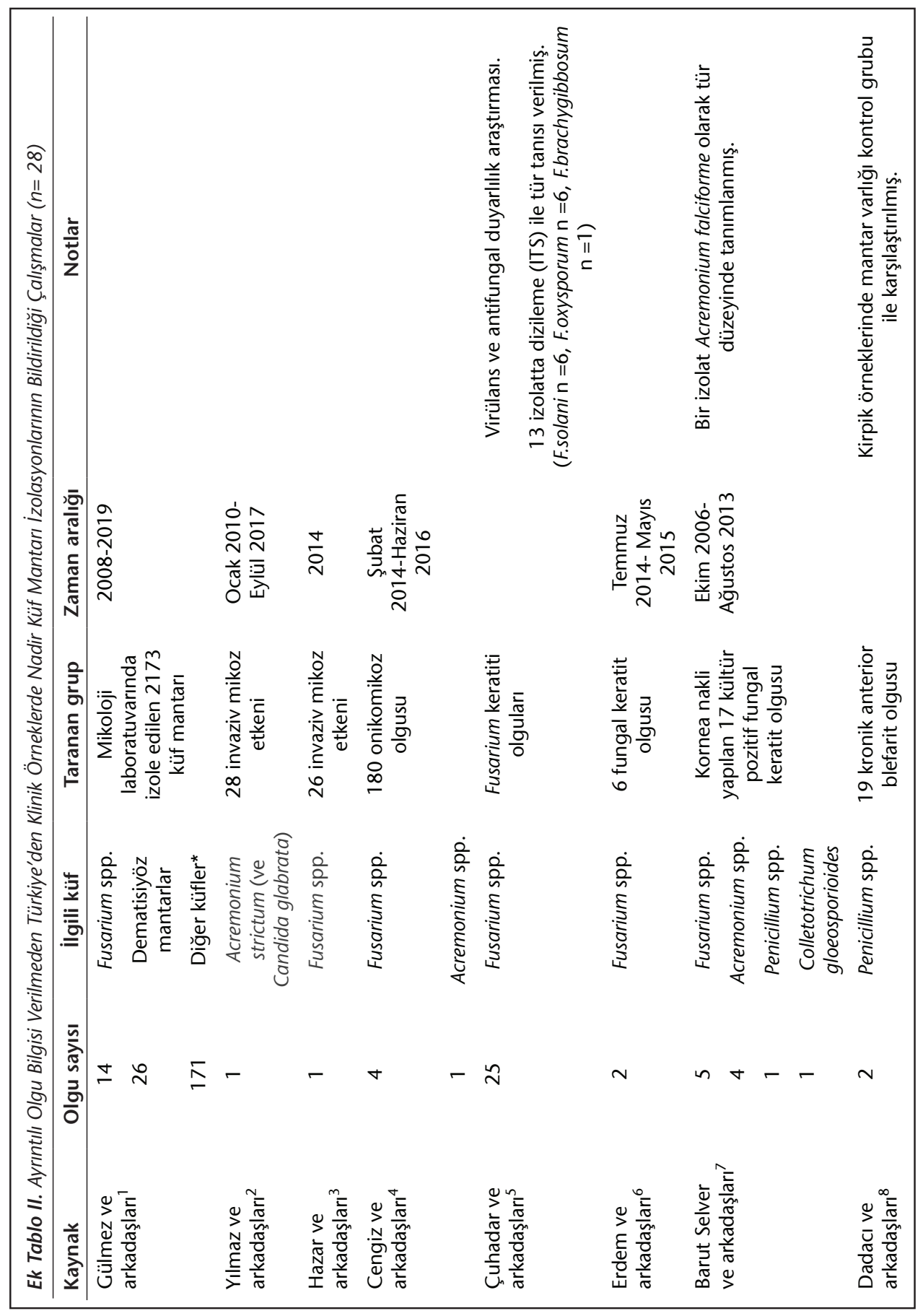




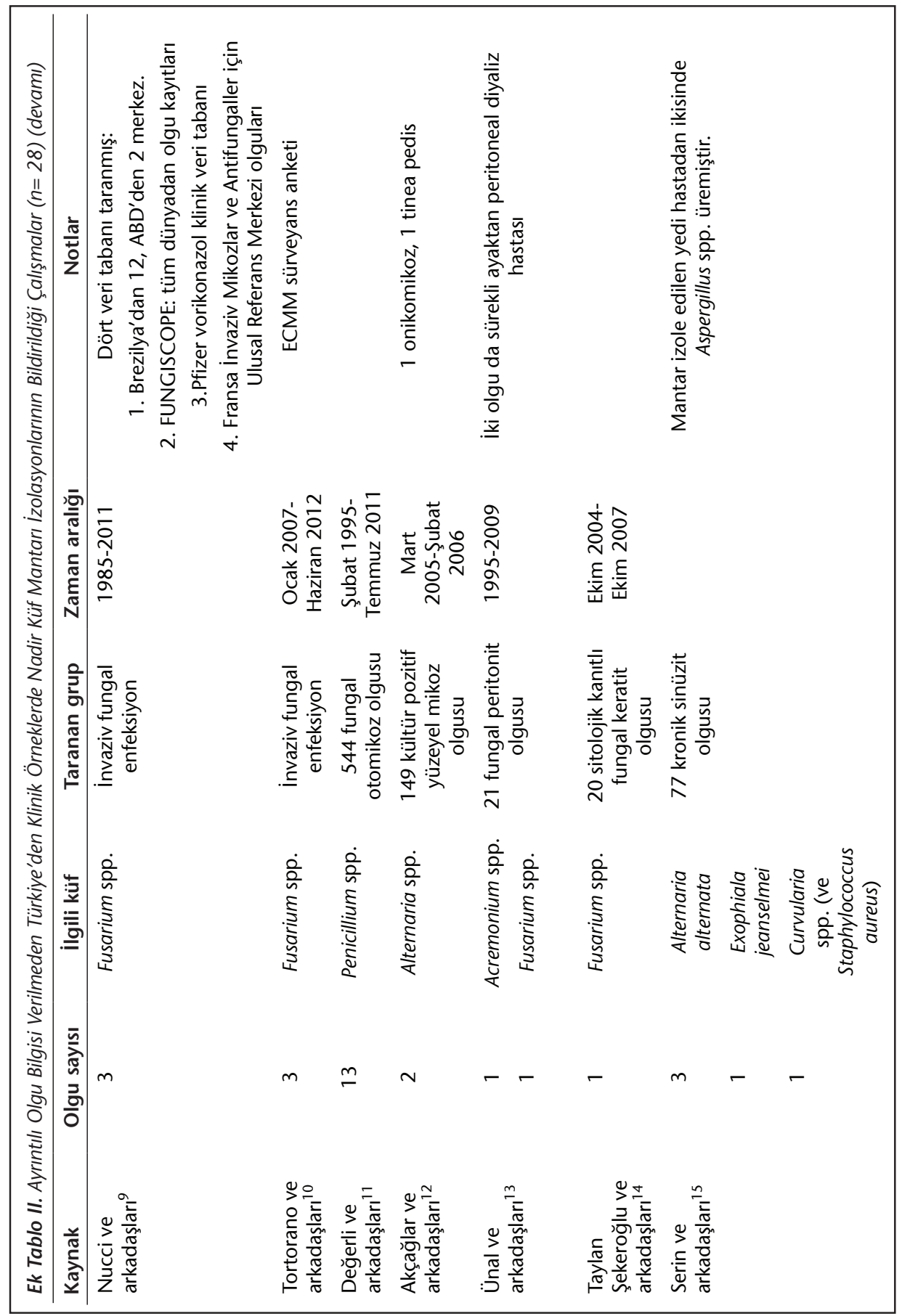




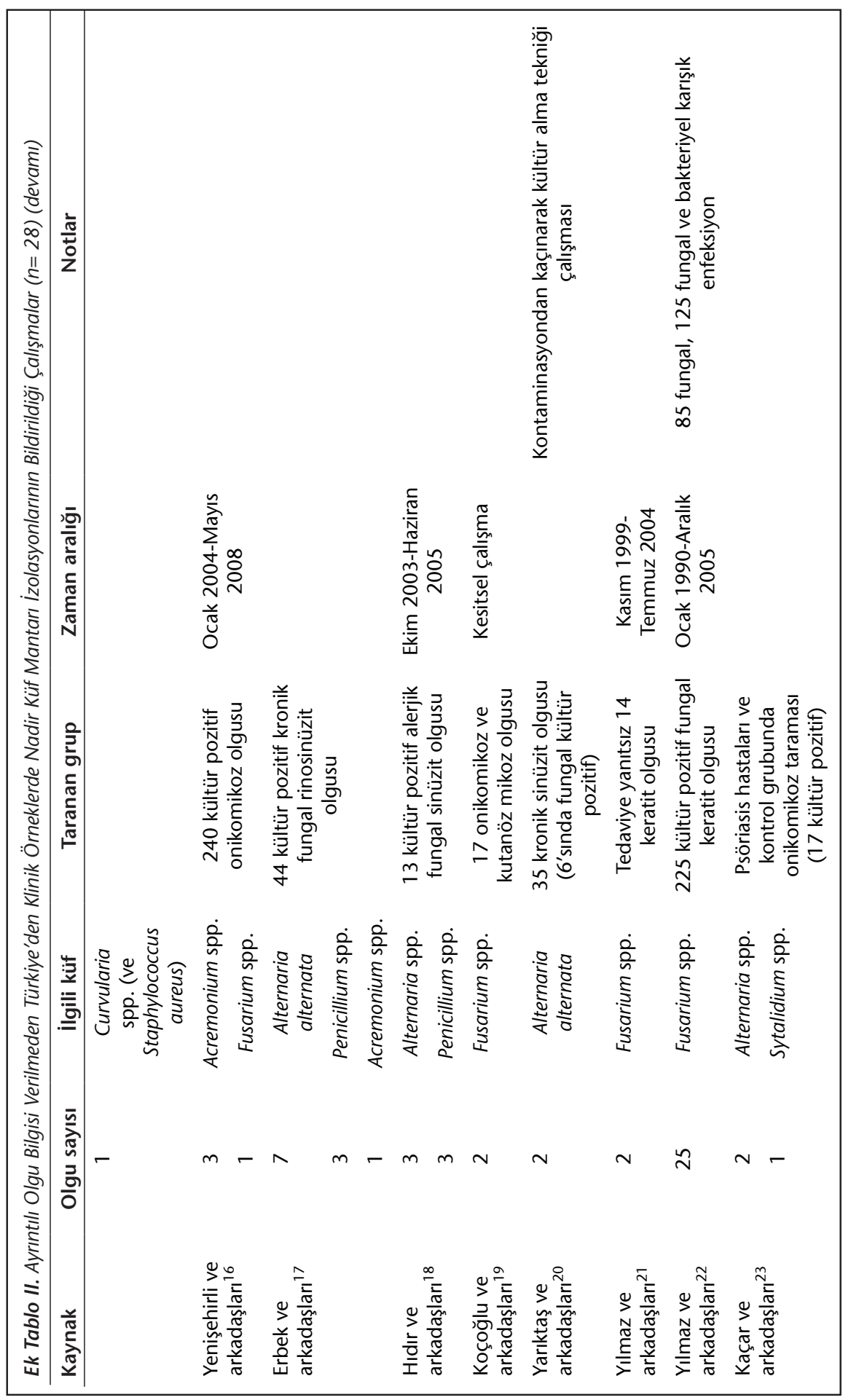




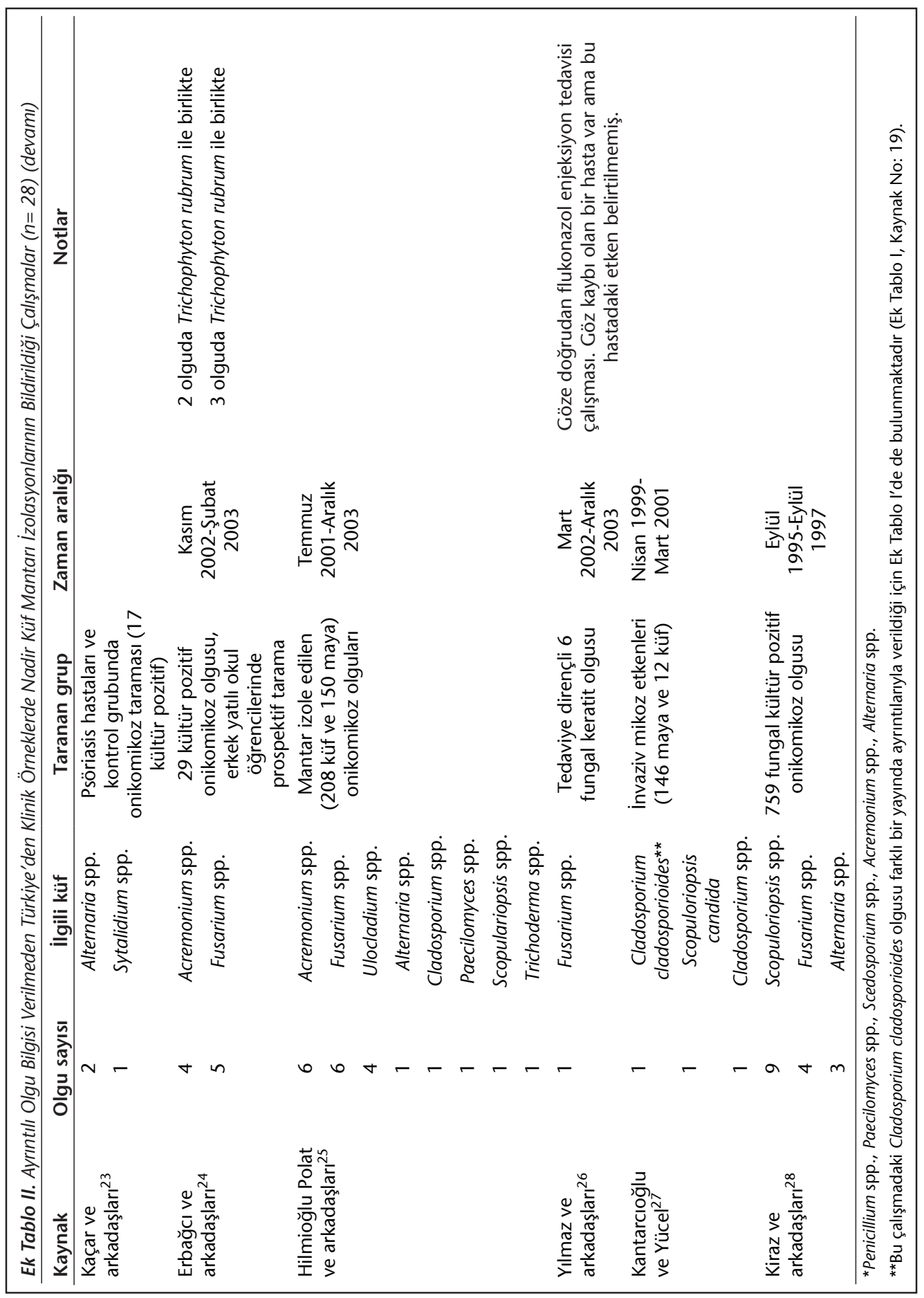




\section{EK 2 KAYNAKLAR}

1. Gülmez D, Sığ AK, Akar N, Duyan S, Arıkan Akdağlı S. Changing trends in isolation frequencies and species of clinical fungal strains: what do the 12-years (2008-2019) mycology laboratory data tell about? Mikrobiyol Bul 2021; 55(1): 53-66.

2. Yılmaz E, Erdoğmuş A, Özcan A, Görkem SB, Ceylan Ö, Deniz K, et al. Invasive fungal infections in children with acute lymphoblastic leukemia: experience from a reference university hospital in Cappadocia. UHOD 2020; 30(3).

3. Hazar V, Karasu GT, Uygun V, Öztürk G, Kılıç ŞK, Küpesiz A, et al. Risks and outcomes of invasive fungal infections in pediatric allogeneic hematopoietic stem cell transplant recipients receiving fluconazole prophylaxis: a multicenter cohort study by the Turkish Pediatric Bone Marrow Transplantation Study Group. Med Mycol 2019; 57(2): 161-70.

4. Cengiz FP, Çevirgen Cemil B, Emiroğlu N, Bahalı AG, Özkaya DB, Su Ö, et al. Etiology of onychomycosis in patients in Turkey. J Am Podiatr Med Assoc 2018; 108(3): 253-6.

5. Çuhadar T, Karabıçak N, Özdil T, Özgür D, Otağ F, Hızel K, et al. Detection of virulence factors and antifungal susceptibilities of Fusarium strains isolated from keratitis cases. Mikrobiyol Bul 2018; 52(3): 247-58.

6. Erdem E, Yağmur M, Boral H, Illkit M, Ersöz R, Seyedmousavi S. Aspergillus flavus keratitis: experience of a tertiary eye clinic in Turkey. Mycopathologia 2017; 182(3-4): 379-85.

7. Barut Selver O, Egrilmez S, Palamar M, Arıcı M, Polat SH, Yağcı A. Therapeutic corneal transplant for fungal keratitis refractory to medical therapy. Exp Clin Transplant 2015; 13(4): 355-9.

8. Dadacı Z, Kılınç F, Özer TT, Şahin GO, Acir NO, Borazan M. Periodic acid-Schiff staining demonstrates fungi in chronic anterior blepharitis. Eye (Lond) 2015; 29(12): 1522-7.

9. Nucci M, Marr KA, Vehreschild MJ, de Souza CA, Velasco E, Cappellano, et al. Improvement in the outcome of invasive fusariosis in the last decade. Clin Microbiol Infect 2014; 20(6): 580-5.

10. Tortorano AM, Prigitano A, Esposto MC, Arsenijevic VA, Kolarovic J, Ivanovic D, et al. European Confederation of Medical Mycology (ECMM) epidemiological survey on invasive infections due to Fusarium species in Europe. Eur J Clin Microbiol Infect Dis 2014; 33(9): 1623-30.

11. Değerli K, Ecemiş T, Günhan K, Başkesen T, Kal E. Agents of otomycosis in Manisa region, Turkey, 1995-2011. Mikrobiyol Bul 2012; 46(1): 79-84.

12. Akçaglar S, Ener B, Toker SC, Ediz B, Tunalı Ş, Töre O. A comparative study of dermatophyte infections in Bursa, Turkey. Med Mycol 2011; 49(6): 602-7.

13. Ünal A, Koçyiğit I, Sipahioğlu MH, Tokgöz B, Oymak O, Utaş C. Fungal peritonitis in peritoneal dialysis: an analysis of 21 cases. Int Urol Nephrol 2011; 43(1): 211-3.

14. Taylan Şekeroğlu H, Yar K, Erdem E, Uğuz A, Yağmur M, Ersöz C, et al. Sitolojik olarak tanısı konulmuş fungal keratitler: klinik özellikleri ve tedavi sonuçları. TJO 2010; 40255-9.

15. Serin B, Bora F, Erdenen F, Sander S, Ulutürk R, Hüten O. Kronik sinüzit nedeniyle opere edilen hastalarda allerjik fungal sinüzit sıklığı. İstanbul Tıp Derg 2009; 10(3): 119-25.

16. Yenişehirli G, Bulut Y, Sezer E, Günday E. Onychomycosis infections in the Middle Black Sea Region, Turkey. Int J Dermatol 2009; 48(9): 956-9.

17. Erbek SS, Şerefhanoğlu K, Erbek S, Demirbilek M, Can F, Tarhan E, et al. Clinical subgroups and antifungal susceptibilities in fungal culture-positive patients with chronic rhinosinusitis. Eur Arch Otorhinolaryngol 2008; 265(7): 775-80.

18. Hıdır $Y$, Tosun F, Saraçlı MA, Günal A, Güleç M, Yetişer S. Rate of allergic fungal etiology of chronic rhinosinusitis in Turkish population. Eur Arch Otorhinolaryngol 2008; 265(4): 415-9.

19. Koçoğlu E, Göksügür N, Karabay O, Özbostancı B, İnce N, Parlak AH. Huzurevi sakinlerinde dermatofit infeksiyonları. Turk Mikrobiyol Cemiy Derg 2007; 37(4): 209-12.

20. Yarıktaş M, Demirci M, Döner F, Tuz M, Aynalı G. Microbiologic findings of sinusitis by a novel method for obtaining culture. Diagn Microbiol Infect Dis 2007; 58(1): 49-52. 
21. Yılmaz S, Türe M, Maden A. Efficacy of intracameral amphotericin B injection in the management of refractory keratomycosis and endophthalmitis. Cornea 2007; 26(4): 398-402.

22. Yılmaz S, Öztürk I, Maden A. Microbial keratitis in West Anatolia, Turkey: a retrospective review. Int Ophthalmol 2007; 27(4): 261-8.

23. Kaçar N, Ergin S, Ergin C, Erdoğan BS, Kaleli I. The prevalence, aetiological agents and therapy of onychomycosis in patients with psoriasis: a prospective controlled trial. Clin Exp Dermatol 2007; 32(1): 1-5.

24. Erbağcı Z, Tuncel A, Zer Y, Balcı I. A prospective epidemiologic survey on the prevalence of onychomycosis and dermatophytosis in male boarding school residents. Mycopathologia 2005; 159(3): 347-52.

25. Hilmioğlu Polat S, Metin DY, İnci R, Kılınç I, Tümbay E. Non-dermatophytic molds as agents of onychomycosis in Izmir, Turkey - a prospective study. Mycopathologia 2005; 160(2): 125-8.

26. Yılmaz S, Maden A. Severe fungal keratitis treated with subconjunctival fluconazole. Am J Ophthalmol 2005; 140(3): 454-8.

27. Kantarcıoğlu S, Yücel A. Mikrobiyoloji ve klinik mikrobiyoloji anabilim dalı derin mikoz laboratuarında 01 Nisan 1999- 27 Mart 2001 arasında ayrılan maya ve küflerin tür dağılımları ve duyarılıı paterni. Cerrahpaşa Tıp Derg 2002; 33(1): 7-19.

28. Kiraz M, Yeğenoğlu Y, Erturan Z, Anğ Ö. The epidemiology of onychomycoses in İstanbul, Turkey. Mycoses 1999; 42(4): 323-9. 